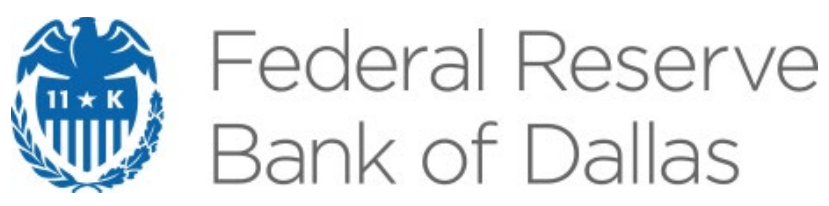

\title{
Are the Largest Banking Organizations Operationally More Risky?
}

Filippo Curti, W. Scott Frame and Atanas Mihov

Research Department

https://doi.org/10.24149/wp2016

Working papers from the Federal Reserve Bank of Dallas are preliminary drafts circulated for professional comment. The views in this paper are those of the authors and do not necessarily reflect the views of the Federal Reserve Bank of Dallas or the Federal Reserve System. Any errors or omissions are the responsibility of the authors. 


\title{
Are the Largest Banking Organizations Operationally More Risky?*
}

\author{
Filippo Curti ${ }^{\dagger}$, W. Scott Frame ${ }^{\ddagger}$ and Atanas Mihov ${ }^{\S}$
}

March 3, 2020

\begin{abstract}
This study demonstrates that, among large U.S. bank holding companies (BHCs), the largest ones are exposed to more operational risk. Specifically, they have higher operational losses per dollar of total assets, a result largely driven by the BHCs' failure to meet professional obligations to clients and/or faulty product design. Operational risk at the largest U.S. institutions is also found to: (i) be particularly persistent, (ii) have a counter-cyclical component (higher losses occur during economic downturns), and (iii) materialize through more frequent tail-risk events. We illustrate two plausible channels of $\mathrm{BHC}$ size that contribute to operational risk - institutional complexity and moral hazard incentives arising from "too-big-to-fail." Our findings have important implications for large banking organization performance, risk, and supervision.
\end{abstract}

Keywords: Banking organizations; Size; Operational risk; Tail risk; Recessions

JEL Classification: G20, G21

\footnotetext{
*We have benefited from discussions with Azamat Abdymomunov, Gara Afonso, Patrick de Fontnouvelle, Marco Migueis and James Vickery. We thank Jeffrey Cheng and Cooper Killen for research assistance. All remaining errors are our own. The views expressed in this paper do not necessarily reflect the position of the Federal Reserve Bank of Richmond, the Federal Reserve Bank of Atlanta, the Federal Reserve Bank of Dallas or the Federal Reserve System.

${ }^{\dagger}$ Filippo Curti, Senior Financial Economist, Federal Reserve Bank of Richmond, filippo.curti@rich.frb.org.

‡W. Scott Frame, Vice President, Federal Reserve Bank of Dallas, scott.frame@dal.frb.org.

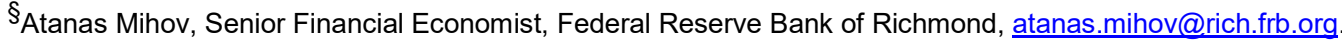




\section{Introduction}

The largest U.S. banking organizations have grown substantially in recent years through a combination of mergers and acquisitions and organic growth (Kovner et al. (2014), Adams and Driscoll (2018)). In 2000, the four largest U.S. bank holding companies (BHCs) held combined assets representing $23 \%$ of the nation's banking industry. By the end of 2016, the proportion had grown to $42 \%$ as the same institutions had more than tripled in size.

This banking industry consolidation has been driven in large part by technological changes arising from advances in telecommunications and information technology (Frame and White (2014)). Consistent with this, recent research indicates that the larger scale and broader scope of activities undertaken by large U.S. banking organizations have resulted in improved cost efficiency (Feng and Serletis (2010), Wheelock and Wilson (2012), Hughes and Mester (2013), Kovner et al. (2014)). These efficiency gains, however, are not translating into higher values for largest BHCs (Sarin and Summers (2016), Minton et al. (2019)). So, what are the value-destroying channels that counteract scale and scope economies at large BHCs?

This paper explores operational risk as one potential channel through which there may be organizational diseconomies of scale. Operational risk refers to losses resulting from inadequate or failed internal processes, people, and systems or from external events (Basel Committee on Banking Supervision (2006)). This risk is particularly difficult to measure, monitor and manage when compared to other key banking risks such as credit and market risks. Operational risk is a major risk category for U.S. bank holding companies and has grown in importance over the last two decades as massive operational losses shook the largest banking organizations in the U.S. and elsewhere around the world (Abdymomunov et al. (2020), Afonso et al. (2019)). For example, Wells Fargo recently experienced a number of costly operational failures, including opening millions of unauthorized customer accounts and engaging in consumer abuses in the mortgage and auto insurance markets. As a result 
of its misconduct, the bank has paid billions of dollars in penalties and settlements, and has been barred by its supervisors from growing assets above 2017 levels until the issues have been resolved. This and other scandals have tarnished the reputations of major bank brands and resulted in a political debate about the social value of very large financial institutions and whether some of them have become "too big to manage." 1

The relation between $\mathrm{BHC}$ size and operational risk is a priori unclear. On the one hand, larger banking organizations might have lower operational risk due to economies of scale in information technology and risk management (Ellul and Yerramilli (2013), Kovner et al. (2014)) or more intense supervisory attention (Hirtle et al. (2018)). Alternatively, these institutions might have higher operational risk as a result of increased complexity (Chernobai et al. (2018)), or risk-taking incentives related to being considered "too-big-tofail" (Gropp et al. (2011), Afonso et al. (2014)). In this study, we examine the association between operational risk and size empirically and thereby document the "net effect" of these countervailing channels.

A major advantage of our study is the use of high-quality supervisory data reported by large U.S. bank holding companies to the Federal Reserve System for stress testing purposes as mandated by the Dodd-Frank Wall Street Reform and Consumer Protection Act. De Fontnouvelle et al. (2006) caution that public sources of data built from press accounts can miss many operational loss events, some of which are large. By contrast, the confidential supervisory data we analyze does not suffer from such issues and is very rich and comprehensive at the individual company level. While the data is limited to the 38 largest U.S. BHCs, these institutions currently account for more than $85 \%$ of banking industry assets.

Our results can be summarized as follows. First, we document a positive and statisti-

\footnotetext{
${ }^{1}$ See (i) Federal Reserve System: "Responding to widespread consumer abuses and compliance breakdowns by Wells Fargo, Federal Reserve restricts Wells' growth until firm improves governance and controls. Concurrent with Fed action, Wells to replace three directors by April, one by year end" (Feb. 02, 2018); and (ii) CBS News: "Wells Fargo "too big to manage," lawmaker tells CEO" (K. Gibson, Mar. 12, 2019).
} 
cally significant association between operational risk and banking organization size. For our sample of large BHCs, a $1 \%$ increase in BHC total assets is associated with a $1.2 \%$ increase in operational losses, suggesting larger BHCs experience higher operational losses per dollar of assets. In dollar terms, a one standard deviation increase in log-transformed total assets translates into $\$ 106.78$ increase in quarterly operational losses per $\$ 1$ million of BHC assets on average. The positive association between operational risk and size is robust to instrumental variable (IV) regressions where bank size is instrumented for by either peer BHCs' operational losses or number of employees. One type of loss events are the principal driver of the relation between operational risk and bank size: failures in obligations to clients, faulty product design, and business practices.

We conduct additional exercises in order to better understand the association between banking organization size and operational losses. First, we show that past operational problems are particularly persistent and hard to eradicate at the largest banking organizations. By contrast, past operational losses are generally negatively related to future operational loss occurrences at the smaller BHCs in our sample. This suggests that the large institutions' scale might be an obstacle to quickly reforming and eradicating operationally risky practices. Second, we document that operational losses at the largest BHCs are especially high during economic downturns, which are often accompanied by financial sector stress. During such adverse conditions, more operational losses at these systemically important BHCs may further destabilize them with potentially significant spill-over effects to the whole financial system. Finally, we show that BHC size is also positively associated with the frequency of tail operational risk events. Tail risk poses difficulties for banking organization capital planning and management, and is particularly relevant for BHC risk of failure.

Our study contributes to the literature on operational risk at financial institutions. Jarrow (2008) describes operational risk from an economic and mathematical perspective with an emphasis on economic capital estimation. Cummins et al. (2006) and Gillet et al. (2010) 
analyze stock market reactions to operational loss announcements at financial institutions. Allen and Bali (2007) investigate the cyclicality in operational risk based measures derived from equity returns. Cope and Carrivick (2013) and Abdymomunov et al. (2020) explicitly link operational risk to the state of the macroeconomic environment and analyze financial industry operational losses over the 2008 crisis period. Cope et al. (2012) investigate the relation between operational loss severity and a number of regulatory, legal, geographical, and economic development indicators in a cross-country analysis. Chernobai et al. (2011) and Wang and Hsu (2013) show that corporate governance is related to the likelihood and frequency of operational risk events at financial institutions. Similarly, Abdymomunov and Mihov (2019) find that BHCs with better risk management quality have lower operational risk. Chernobai et al. (2018) show that BHC expansions into non-banking activities result in more operational risk.

By contrast, this study examines the relation between bank size and operational risk at large banking organizations. While it is only natural that the largest financial institutions will incur more operational losses in dollar terms, we show that they incur more operational losses per dollar of total assets. Our findings further highlight that operational risk at the largest BHCs is particularly persistent, tends to occur in adverse economic conditions and manifests more frequently through high-severity tail events.

Our study also has implications for the literature linking financial institution size and market value. Minton et al. (2019) provide cross-sectional evidence that the valuation of large banks falls with size and Sarin and Summers (2016) document a dramatic decline in the franchise value of major banks over time. Moreover, Demirgüç-Kunt and Huizinga (2013) find that market-to-book ratios are inversely related to bank size in an international sample of banks, suggesting that the negative relation between bank value and size is not simply a U.S. phenomenon. While we do not take a direct stand on whether bank size increases or decreases bank value, our research points to a specific channel through which banking 
organization size destroys value at the largest institutions - higher operational losses.

The results of our analysis are also relevant for supervisory policy regarding large banking organizations. Our findings that the largest U.S. BHCs are substantially more exposed to operational risk suggest that enhanced risk management practices at - and increased supervisory attention on - these institutions is warranted. This conclusion is consistent with the Federal Reserve's current approach of imposing different expectations for sound capital planning and capital adequacy depending on the size, scope of operations, activities, and systemic importance of BHCs (e.g., significantly heightened expectations for the largest and most systemically important U.S. banking organizations). ${ }^{2}$ Moreover, the existence of amplifying channels for the very largest banking organizations associated with past operational losses and macro-financial stress may inform both micro-prudential (e.g., institution-focused supervision) and macro-prudential regulatory policies (e.g., stress testing). First, optimal supervision intensity at the largest BHCs may depend on past operational loss experiences. Specifically, the recent experience of operational losses at the largest banking organizations suggests that increased supervisory attention and improved risk management practices could help to reduce such losses in the future. Second, prudential regulations should reflect the increased sensitivity of operational risk to economic downturns at the largest BHCs and require sufficient capital to absorb related losses.

The rest of this paper is organized as follows. Section 2 develops our hypotheses. Section 3 describes our data, the construction of variables and descriptive statistics. Section 4 presents our main empirical results. Section 5 checks for robustness. Finally, Section 6 concludes.

\footnotetext{
${ }^{2}$ See, for example, supervision and regulation letters SR 15-18 and SR 15-19. More information on SR 15-18 can be found at: https://www.federalreserve.gov/supervisionreg/srletters/sr1518.htm. Information on SR 15-19 can be found at: https://www.federalreserve.gov/supervisionreg/srletters/sr1519.htm.
} 


\section{Hypothesis Development}

This section discusses the potential channels through which banking organization size may be related to operational risk. With competing effects at play, the direction of the relationship is a priori unclear.

On one hand, larger banks could be more exposed to operational risk. One channel is through complexity. Laeven and Levine (2007) argue that business complexity contributes to intensified agency problems at financial conglomerates, which could manifest through reduction of managerial effort, inadequate (operational) risk controls, or even the outright expropriation of shareholders (e.g., insider fraud). In a similar vein, Chernobai et al. (2018) contend that increased complexity can render managerial oversight less efficient and hinder information exchanges between different business segments. Multiple business lines, combined with aggressive sales cultures, could contribute to misguided incentives that result in improper marketing and sales practices or faulty product designs that lead to regulatory fines and legal losses.

A second channel for a positive association between size and operational risk is that the very largest BHCs might have a greater risk appetite (moral hazard) arising from a greater likelihood of government support (Afonso et al. (2014)). Importantly, moral haz-

ard might not only manifest through increased risk-taking, but also equivalently through under-investment in risk management infrastructure. Increased risk-taking associated with government guarantees at one large banking organization might additionally spill over to peer institutions through competition and interconnectedness effects (Gropp et al. (2011)). These arguments lead to the following hypothesis:

Hypothesis 1a: Larger banking organizations have more operational risk.

Larger banking organizations, on the other hand, could have lower exposure to operational risk. One channel is through increased regulation and supervision. Hirtle et al. 
(2018) show that the largest BHCs are supervised more intensively and are consequently less risky (e.g., have lower stock return volatility, hold less risky loan portfolios, engage in more conservative reserving practices, etc.). A second channel for a negative association between operational risk and bank size is that larger banks might have increased efficiency arising from scale economies in information technology and risk management (Kovner et al. (2014)), which could consequently translate into better risk management quality (Ellul and Yerramilli (2013)). A third prospective driver of a negative relationship is diversification. Diversification may limit over-exposures to only few risky business lines and ensure that potential risk management failures remain relatively contained to individual business segments. Collectively, this second set of arguments leads to the alternative hypothesis:

Hypothesis 1b: Larger banking organizations have less operational risk.

With these potential counter-veiling effects, the issue of whether larger banking organizations have more operational risk is an empirical matter. It is important to note that the empirical dominance of either of the above hypotheses reflects the "net effects" of BHC size on operational risk.

\section{Data Sample and Variable Definitions}

\subsection{Operational Loss Data}

This study uses supervisory data of operational losses submitted by large U.S. bank holding companies pursuant to the Dodd-Frank Wall Street Reform and Consumer Protection Act. The Federal Reserve System collects such data for stress testing purposes under the Comprehensive Capital Analysis and Review (CCAR) program. The data follows FR Y-14Q reporting requirements (current as of April 2017) and is provided by 38 financial institutions that participated in the 2017 Dodd-Frank Act Stress Test (DFAST) program with consol- 
idated assets of $\$ 50$ billion or more. ${ }^{3}$ Although our operational loss data comes from a relatively small number of institutions, these institutions account for the majority of U.S. bank industry assets (85.2\% as of 2016:Q4). Furthermore, while the data collection requirements necessarily screen out small banking organizations, we note the significant variation in BHC size in our sample with institutions ranging from $\$ 50$ billion to $\$ 2.5$ trillion in consolidated total assets. The data is highly granular and provides information such as loss amounts, loss classifications and loss descriptions.

Banking organizations subject to the regulation have different thresholds for collecting individual operational losses. To mitigate the impact of firm heterogeneity in collection thresholds on our results, we follow prior research (e.g., Abdymomunov et al. (2020)) and discard operational losses below $\$ 20,000$, the highest threshold across reporting institutions. The final sample contains 299,673 individual loss events from a total of 38 large BHCs over the period [2001:Q1-2016:Q4]. Our data is substantially richer than counterparts offered by private vendors. For instance, Chernobai et al. (2011) use a sample with 2,426 loss events from Algo FIRST and Hess (2011) uses around 7,300 loss events from SAS OpRisk Global Data. Furthermore, as discussed in de Fontnouvelle et al. (2006), operational risk data sets based on publicly available information are likely to omit substantial losses otherwise contained in the supervisory data that we use.

Each loss instance reports occurrence, discovery, and accounting dates. The data reporting instructions define these dates as follows: (i) occurrence date - the date when the operational loss event occurred or began; (ii) discovery date - the date when the operational loss event was first discovered by the institution; and (iii) accounting date - the date when the financial impact of the operational loss event was recorded on the institution's

\footnotetext{
${ }^{3}$ More information about FR Y-14Q reporting requirements, instructions and forms can be found at: http://www.federalreserve.gov/apps/reportforms/. Subsequent to the Economic Growth, Regulatory Relief, and Consumer Protection Act of 2018, financial institutions with under $\$ 100$ billion in total assets are no longer required to file the FR Y-14Q reports, effective May 2018.
} 
financial statements. To examine the relationship between operational risk and BHC size, our analysis aggregates loss data at the bank-quarter level, where we use the quarter of occurrence for aggregation purposes. ${ }^{4}$ In particular, we build an unbalanced panel of 1,343 bank-quarter observations over the period [2001:Q1-2016:Q4] in accordance with individual bank data availability.

\subsection{Operational Risk Variables}

Table 1 presents variable definitions. Our main measure of operational risk is the total dollar value of operational losses that occur at a BHC in a given quarter. We follow Abdymomunov and Mihov (2019) and other studies in the literature on bank risk and performance (e.g., James (1991), Ahmed et al. (1999), Ellul and Yerramilli (2013)), and scale losses by BHC asset size. For presentation purposes, we multiply the loss-to-assets ratio by 1,000 and call it $L t A$. In some of our regression specifications, we also use log-transformed dollar losses, Ln(Loss), log-transformed frequency of operational loss events, Ln(Freq), and logtransformed average operational loss amount (severity), Ln(Sev), that occur at an institution in a given quarter.

[Insert Table 1 about here]

Table 2 presents descriptive statistics. On average, the BHCs in our sample lose $\$ 200$ million or the equivalent of $0.0265 \%$ of their assets per quarter to operational risk. Further, the standard deviations of both dollar losses ( $\$ 1.1$ billion) and asset-scaled operational losses $(0.1011 \%)$ are high relative to the means, indicating substantial time-series and crosssectional variation of operational losses. On average, 223 operational loss events with an average severity of $\$ 0.6$ million occur at an institution over a given quarter.

\footnotetext{
${ }^{4}$ Our results are also robust to using discovery dates or accounting dates for loss aggregation.
} 
[Insert Table 2 about here]

A well-known property of operational losses is the extremely heavy tails of the empirical loss distributions (Chernobai and Rachev (2006), Jobst (2008)). Indeed, only a few "catastrophic" operational risk events account for a large proportion of the total dollar losses in our sample. Thus, while we focus on quarterly operational losses at BHCs, we also analyze tail operational risk. To measure tail operational risk, we start with the 299,673 individual loss events in our sample and scale dollar loss amounts by BHC total assets. We calculate the $99.9^{\text {th }}$ quantile of the resulting empirical distribution and categorize all loss events with severities above this quantile as "tail losses." We then "collapse" the sample of losses at the BHC-quarter level by counting the number of tail events that occur at a given institution during a given quarter $(N$ Tail). Finally, we take a natural log transformation of the number of tail events ( $\operatorname{Ln}(N$ Tail $))$.

\subsection{Measure of BHC Size and Control Variables}

We use the natural log transformation of BHC total consolidated assets, Ln(Assets), as our main measure of banking organization size. ${ }^{5}$ Our multivariate regression analysis also includes a number of BHC-level variables to control for confounding effects. First, we include a detailed set of variables to capture business area exposures for each BHC. Specifically, we include the proportion of revenue coming from: interest income on loans and leases (Loans and Leases), interest income on investment securities (Investment Securities), income from fiduciary activities (Fiduciary Activities), trading revenue (Trading), income from investment banking, advisory, brokerage and underwriting fees (Investment Banking), venture capital revenue (Venture Capital), securitization income (Securitization) and servicing fees revenue

\footnotetext{
${ }^{5}$ Our results are also robust to using alternative BHC size measures such as total liabilities, and book and market value of equity.
} 
(Servicing Fees).

Second, we control for BHC risk. We include past operational losses averaged over trailing 12 quarters $([-12,-1])$ and scaled by average assets over the same period (Past Op Losses). ${ }^{6}$ This variable should capture a banking organization's particular exposures to operational risk as well as the quality of their risk management functions with regards to operational risk (Curti and Migueis (2019)). Because operational risk is closely related to credit risk as argued by Chernobai et al. (2011), we also control for a BHC's loan charge-off rate (Loan Losses). Finally, we control for the BHC's contemporaneous tier 1 risk-based capital (Tier 1 Capital).

\subsection{Pairwise Correlations and Univariate Sorts}

As a first step towards explaining the relation between the intensity of operational risk and banking organization size, we start with a simple correlation analysis. Table 3, Panel A reports pairwise correlation coefficients between $L n$ (Assets) and our primary operational risk variables. Most notably, the correlation between $L n$ (Assets) and $\operatorname{Ln}(L)$ is $75 \%$, suggesting that the larger BHCs in our sample incur more operational risk in dollar terms. Additionally, the correlation between Ln(Assets) and $L t A$ is $15 \%$, further indicating that larger BHCs not only have more operational losses in dollar terms, but also incur more operational risk per dollar of assets. In both cases, the correlation coefficients are significant at the $1 \%$ level.

We also highlight this last point visually in Figure 1. This figure presents linear and quadratic fits of the relation between $L t A$ and $L n$ (Assets), where both LtA and Assets are averaged within BHCs over time. The figure shows that larger BHCs clearly incur more operational risk per dollar of assets, and this relationship becomes stronger as institution size increases.

\footnotetext{
${ }^{6}$ Our results are also robust to using alternative windows for averaging past losses.
} 
[Insert Table 3 and Figure 1 about here]

We next show similar results in a BHC group analysis. Specifically, we sort banking organizations into terciles ("Small," "Medium" and "Large") according to Assets every quarter. We then calculate averages of operational risk variables for each tercile and calculate the mean difference across the Large and the Small terciles. Table 3, Panel B presents the results. Consistent with the evidence from Panel A, the smaller BHCs in our sample have lower operational risk than the larger BHCs. The difference in the group means is statistically significant at the $1 \%$ level. Figure 2, which presents a bar chart of the average $L t A$ for BHCs sorted in terciles based on total assets, reinforces this point visually — the larger BHCs incur more operational losses per dollar of assets than smaller BHCs.

[Insert Figure 2 about here]

\section{Regression Results}

\subsection{Operational Losses}

To further examine whether larger banking organizations have more operational risk, we estimate the following specification using OLS:

$$
\text { Op } \text { Loss }_{i, t}=\beta_{t}+\beta_{1} \operatorname{Ln}(\text { Assets })_{i, t}+\beta_{2} \operatorname{Ctrls}_{i, t}+\epsilon_{i, t}
$$

where $i$ indexes BHCs and $t$ indexes time periods (quarters). Op Loss $s_{i, t}$ is one of four operational loss measures: (i) operational losses as a proportion of total assets that occur at BHC $i$ during quarter $t(L t A)$; (ii) log-transformed operational dollar losses that occur at BHC $i$ during quarter $t$; (iii) log-transformed frequency of operational losses that occur 
at $\mathrm{BHC} i$ during quarter $t$; or (iv) log-transformed average severity of operational losses that occur at BHC $i$ during quarter $t$. $C t r l s_{i, t}$ represents our previously discussed vector of control variables for $\mathrm{BHC}$ business lines and risk. We cluster standard errors at the $\mathrm{BHC}$ and quarter levels to account for within-bank and within-quarter correlation of the error terms, and include quarter fixed effects $\left(\beta_{t}\right)$ to absorb potential period-specific shocks to operational risk occurrences. Table 4 presents the results.

[Insert Table 4 about here]

The results in Column (1) suggest that larger banking organizations experience more operational losses per dollar of assets. The coefficient estimate of Ln(Assets) is positive and statistically significant at the $5 \%$ level. A one standard deviation increase in Ln(Assets) is associated with a $\$ 106.78$ increase in quarterly operational losses per $\$ 1$ million of $\mathrm{BHC}$ assets, which is a $40.3 \%(=(0.095 \times 1.124) / 0.265)$ increase in $L t A$ relative to its mean. Column (2) provides consistent evidence, which suggests that a $1 \%$ increase in BHC total assets is associated with a $1.2 \%$ increase in operational losses. Further, Columns (3) and (4) indicate that larger banking organizations experience more frequent and more severe operational losses.

Focusing on Column (1), which uses our main dependent variable (LtA), we find that the estimated coefficients on the control variables are mostly insignificant, with two exceptions. First, BHCs with a greater proportion of revenue coming from interest on loans and leases have lower operational losses. In other words, traditional bank lending is operationally less risky. Second, BHCs with larger past losses have higher operational losses. This suggests that BHCs with recent records of operational problems (e.g., due to risky practices and activities or inadequate risk management) have higher operational risk exposure. We come back to this last finding and examine possible interaction effects with BHC size in Section 
4.3 .

\subsection{Operational Loss Event Types}

Operational risk has many different causes. Losses in our sample are categorized into seven event types (consistent with Basel II Accord classifications): Internal Fraud (IF), External Fraud (EF), Employment Practices and Workplace Safety (EPWS), Clients, Products and Business Practices (CPBP), Damage to Physical Assets (DPA), Business Disruption and System Failures (BDSF), and Execution, Delivery and Process Management (EDPM). Table 1 includes definitions and Figure 3 presents the allocation of dollar losses across the seven loss event type categories. The figure suggests that the most significant portion of losses, $79.6 \%$ or $\$ 213.9$ billion, can be traced to the Clients, Products and Business Practices event type. The second most significant event type is Execution, Delivery and Process Management, which accounts for $12.0 \%$ or $\$ 32.2$ billion. Notably, CPBP and EDPM together accounted for more than $90 \%$ of operational losses at large BHCs over our sample period. On the other side of the spectrum, Business Disruption and System Failures is the most insignificant event type, which accounts for only $0.5 \%$ or $\$ 1.3$ billion of the losses in our sample.

[Insert Figure 3 about here]

In the previous section, we documented a significant relationship between operational losses and $\mathrm{BHC}$ size after aggregating losses across all seven categories and ignoring the heterogeneity of operational risk in the different groups. In this section, we re-estimate this relation at the individual loss event category level. Specifically, we re-estimate Equation 1 for each loss event type separately. We note that a priori we do not have a clear expectation

of which particular sub-categories of operational risk exposure are correlated with BHC size. Table 5 presents the results. 
[Insert Table 5 about here]

The coefficient signs of $\operatorname{Ln}$ (Assets) is significantly different from zero in only two specifications - for event type CPBP in Column (4) and event type BDSF in Column (6). As reported in Table 1, Panel A, CPBP captures losses from "[a]n unintentional or negligent failure to meet a professional obligation to specific clients, or from the nature or design of a product" and BDSF captures losses from "[d]isruption of business or system failures." Importantly, while BDSF accounts for a mere $0.5 \%$ of operational losses in our data, CPBP accounts for the majority of BHC operational risk - 79.6\% of total losses. Also important to note is that the coefficient on $L n$ (Assets) is orders of magnitude larger for CPBP relative to BDSF. This finding thus suggests that the strong positive association between operational risk and BHC size is largely driven by one type of operational risk related to failures in obligations to clients and/or product design, which is also supported by anecdotal evidence. For example, the nation's five largest mortgage servicers, including the four largest BHCs in the United States (i.e. Bank of America Corporation, JPMorgan Chase \& Co., Wells Fargo \& Company, Citigroup Inc.), reached a $\$ 25$ billion settlement with the U.S. federal government to address past improper mortgage loan servicing and foreclosure fraud. ${ }^{7}$ Similarly, JPMorgan Chase had multiple settlements totalling over $\$ 13$ billion for risky mortgages sold by Bear Stearns and Washington Mutual prior to the 2008 financial crisis. ${ }^{8}$

\footnotetext{
${ }^{7}$ See Department of Justice, Office of Public Affairs: "Federal Government and State Attorneys General Reach $\$ 25$ Billion Agreement with Five Largest Mortgage Servicers to Address Mortgage Loan Servicing and Foreclosure Abuses" (February 9, 2012).

${ }^{8}$ See Department of Justice, Office of Public Affairs: "Justice Department, Federal and State Partners Secure Record $\$ 13$ Billion Global Settlement with JPMorgan for Misleading Investors About Securities Containing Toxic Mortgages" (November 19, 2013).
} 


\subsection{Past Operational Losses}

As discussed in the introduction, one of the nation's largest banking organizations, Wells Fargo, has been under intense regulatory and public scrutiny since 2016 as a result of its fraudulent practices including deceiving customers with fake bank accounts, unwarranted fees, and unwanted products. Even though the institution has allegedly eliminated aggressive sales targets that arguably spurred the bad behavior in the first place, the organization's culture might be slower to change. A 2019 New York Times report suggests that many Wells Fargo workers remain under heavy pressure to "squeeze extra money out of customers," with internal rules reportedly bent or broken to meet performance goals three years after the scandal erupted. ${ }^{9}$ This anecdotal evidence suggests that questionable employee performance incentives, risk management deficiencies and ensuing risky business practices might be slow eradicate. Some have pointed out that the banking giant's failure to reform might be particularly related to its size and being "too big to manage."

The regression results presented in Table 4 indeed suggest that past operational losses (Past Op Losses) have significantly positive predictive power for current losses that befall BHCs. In this section, we empirically test whether this effect is more pronounced for the largest banking organizations. We estimate models similar to Equation 1, including an interaction term between Ln(Assets) and Past Op Losses, as well as Ln(Assets), Past Op Losses and control variables separately. Table 6 presents the results.

[Insert Table 6 about here]

In Column (1), the coefficient on Past Op Losses ${ }^{*} L n$ (Assets) is positive and statistically significant at the $5 \%$ level. This is consistent with the interpretation that past practices

\footnotetext{
${ }^{9}$ See The New York Times: "Wells Fargo Says Its Culture Has Changed. Some Employees Disagree." (E. Flitter and S. Cowley, Mar. 9, 2019).
} 
conducive to operational losses are particularly hard to address at the larger banking organizations, which consequently result in lingering operational losses.

Column (2) indicates the robustness of our results to discretizing Past Op Losses into a binary variable, Past $O p$ Losses (0/1), which is equal to 1 if Past Op Losses is greater than the sample median, 0 otherwise. The interaction Past Op Losses (0/1)*Ln(Assets) retains a positive sign and is again statistically significant at the $5 \%$ level. Importantly, in both Columns (1) and (2), the stand-alone terms Past Op Losses and Past Op Losses (0/1) are both negative (marginally statistically insignificant at the $10 \%$ level in Column (1)), emphasizing that past operational losses persist only for the largest BHCs and are largely negatively related to current losses for the remaining institutions in our sample.

\subsection{Economic Downturns}

Abdymomunov et al. (2020) document a significant association between U.S. banking organizations' operational losses and the domestic macroeconomic environment. In adverse conditions, BHCs face higher operational losses. In view of our findings that larger BHCs have more operational risk, this motivates us to examine if the macro-economy serves as an amplifying channel for the relationship between banking organization size and operational risk.

To study this issue empirically, we define a time indicator variable, Recession. Recession is equal to 1 for quarters in which the U.S. economy is in recession during our sample period according to the National Bureau of Economic Research (i.e. [2001:Q1-2001:Q4] and [2007:Q4-2009:Q2]), and 0 otherwise. We also decompose Recession to assess the effects of the two recessionary periods in our sample individually. Specifically, 2001 Recession equals 1 for the periods [2001:Q1-2001:Q4], and 0 otherwise. 2008 Recession equals 1 for the periods [2007:Q4-2009:Q2], and 0 otherwise.

We estimate models similar to Equation 1, including interactions between Ln(Assets) and 
Recession (or alternatively, 2001 Recession and 2008 Recession). Because we also include quarter fixed effects as in the prior specifications, we are not able to identify the coefficients on the recession variables individually. Table 7 presents the results.

[Insert Table 7 about here]

Column (1) suggests that larger banking organizations are particularly susceptible to the occurrence of operational losses during recessionary periods. The coefficient on Reces$\operatorname{sion}^{*} \operatorname{Ln}$ (Assets) is positive and statistically significant at the $5 \%$ level. Columns (2) and (3) further suggest that the link between banking organization size and operational risk is amplified during both recessionary periods in our sample. The coefficients of 2001 Reces$\operatorname{sion}^{*} \operatorname{Ln}$ (Assets) and 2008 Recession ${ }^{*} \operatorname{Ln}$ (Assets) are both positive and statistically significant at least at the $10 \%$ level.

\subsection{Tail Operational Risk}

To this point, we have explored the link between banking organization size and operational loss "levels." Here, we focus on how operational tail risk varies in the cross-section in relation to BHC size. The distinction between the average levels of operational risk at an organization and tail risk is important. Higher but stable operational losses have adverse implications for BHC profitability and performance. However, such stable losses are easier to anticipate and reserve for. By contrast, operational tail losses pose difficulties for loss reserving practices and capital management, and are more relevant for BHC risk of failure.

As discussed in Section 3.2, we use the log-transformed frequency of operational risk tail events incurred by a BHC over given quarter $(\operatorname{Ln}(N$ Tail $))$ as a measure of tail risk. The pairwise correlations and univariate sorts in Table 3 provide preliminary evidence that the largest banking organizations experience more tail events. These associations also persist in 
a multivariate regressions setting similar to Equation 1, the results of which are presented in Table 8.

[Insert Table 8 about here]

Columns (1)-(3) present regressions of tail operational risk. Column (1) suggests that a $1 \%$ increase in $\mathrm{BHC}$ total assets is associated with a $0.03 \%$ increase in the frequency of tail operational losses. The coefficient estimates of Ln(Assets) are significant at the $5 \%$ level. Columns (2)-(3) further indicate that our OLS regression results in Column (3) are robust to using count regression models such as Poisson and Negative Binomial regressions. Cross-sectional differences in BHC size are relevant for the incidence of tail operational risk events, with the largest institutions being more susceptible.

In Column (4), we examine whether BHC size exacerbates operational tail risk problems for banking organizations with track records of operational problems (i.e. higher past operational losses). The positive and significant (at the 5\% level) interaction term Past Op Losses*Ln(Assets) suggests so. Larger banking organizations with higher past operational losses experience more frequent tail risk events. In Column (5), we examine whether the incidence of tail operational risk at the largest BHCs is related to the business cycle. Recession ${ }^{*} \operatorname{Ln}($ Assets) is positive and significant (at the $5 \%$ level), suggesting that the tail operational risk frequency is particularly high for the largest institutions during economic downturns. Altogether, our findings indicate that tail operational risk is particularly problematic for the largest institutions in our sample. Its tendency to materialize at the largest BHCs during economic downturns should be a particular source for concern with regards to institutional risk of failure and financial stability. 


\section{Additional Analysis}

\subsection{Channels of BHC Size}

Section 2 discusses two channels through which banking organization size might lead to more operational risk: increased complexity and moral hazard derived from implicit government guarantees ("too-big-to-fail"). This section explores these two channels.

We begin with two measures of BHC organizational and business complexity. First, we calculate the log-transformed number of subsidiaries in a bank holding company's organizational tree $(\operatorname{Ln}(N$ Subsidiaries $))$. Second, we calculate the log-transformed number of distinct industry sectors (4-digit NAICS) in which BHCs operate (Ln(N Segments)). We also synthesize the information in $L n(N$ Subsidiaries $)$ and $L n(N$ Segments $)$ into a single, third measure of complexity by extracting their first principal component (Complexity $(P C)$ ). The source of data for these measures is Federal Reserve's FR Y-10 report. ${ }^{10}$

To proxy for the government's likelihood of intervention in the event of a banking organization's financial distress and associated risk-taking incentives, we use two measures of BHC systemic importance related to financial interconnectedness: the log-transformed intra-financial system assets (Ln(Intra-FS Assets)) and liabilities (Ln(Intra-FS Liabilities)). Intra-FS Assets measures funds lent to financial institutions, unused portion of committed lines extended to financial institutions, holdings of securities issues by other financial institutions, net positive current exposure of securities financing transactions with financial institutions, OTC derivative contracts with financial institutions that have a positive fair value. Intra-FS Liabilities measures deposits due to financial institutions, borrowings obtained from financial institutions, unused portion of committed lines from financial institutions, net negative current exposure of securities financing transactions with financial

\footnotetext{
${ }^{10}$ In unreported tests, we study additional complexity measures such as the notional amount of over-thecounter derivatives, trading and available-for-sale securities, and Level 3 assets (Federal Reserve System (2015)). We find directionally and qualitatively similar results.
} 
institutions, OTC derivative contracts with financial institutions that have a negative fair value.

More holistically, we examine a systemic importance score methodology developed by the Basel Committee on Banking Supervision and used by the Federal Reserve for designating global banking organizations as systemically important. Specifically, GSIB Score aggregates 12 indicators across several conceptual categories: the size of the financial institutions, their interconnectedness, the lack of readily available substitutes for the services they provide, their complexity, and their global (cross-jurisdictional) activities (Federal Reserve System (2015)). The source of data for these measures is the Federal Reserve's FR Y-15 report. Because data from this report are only available for the last several quarters in our sample, we use variables constructed as of 2016:Q4, the last quarter in our sample.

We estimate models similar to Equation 1, where we substitute BHC size (Ln(Assets)) with the above measures of institution complexity and systemic importance. Table 9 presents these results.

[Insert Table 9 about here]

Columns (1)-(3) suggest that more complex banking organizations have more operational losses per dollar of assets. The coefficients of $\operatorname{Ln}(N$ Subsidiaries), Ln(N Segments) and Complexity $(P C)$ are positive and significant at least at the $10 \%$ level. Columns (4)-(6) indicate that more systemically important BHCs are operationally riskier. Ln(Intra-FS Assets), Ln(Intra-FS Liabilities) and GSIB Score are positive and significant at least at the $10 \%$ level. If more systemically important banking organizations have stronger risk-taking incentives, this result indirectly suggests that the effect of size on operational risk exposure is partly through increased risk-taking. Overall, we interpret the evidence from Table 9 to be consistent with bank size effects on operational risk through both complexity and moral 
hazard.

\subsection{Endogeneity and Reverse Causality}

One identification concern that may confound the interpretation of our results is that we are not capturing a relation between operational risk and $\mathrm{BHC}$ size, but rather the relation between operational risk and some uncontrolled institution-specific effect. To address this

concern, we estimate instrumental variable regressions using either the average amount of operational losses or the number of employees of the closest three BHCs in terms of size as instruments. While operational risk or number of employees across banking organizations of similar size should be significantly positively correlated, the operational losses or number of employees of matched institutions should not reflect the latent characteristics of the BHC for which the matched group is created. Table 10 presents the results.

[Insert Table 10 about here]

Table 10, Panel A presents first-stage results. The operational losses and number of employees of closely matched banking organizations (in terms of size) are positively correlated with BHC size. The coefficients of the instrumental variables are highly statistically significant in both specifications, suggesting that the regressions do not suffer from weak instrumental variable problems. Table 10, Panel B presents second-stage results. Here we see that $L n$ (Assets) retains its positive sign and statistical significance in both specifications. The IV analysis therefore suggests that our main results are robust to accounting for omitted bank-specific effects driving the relationship of interest.

A second identification concern could be that there is reverse causation stemming from a feedback loop from operational risk to BHC size. For example, operational risk might reduce total assets through reputation and asset impairment channels. We note two important 
mitigating factors in this regard. First, to the extent that such reverse causality implies a negative correlation between operational risk and bank asset size, it should only bias our results downwards against finding a relation (our results document a positive relation). Second, the use of loss occurrence dates, as opposed to operational loss discovery/accounting dates, to match operational losses and BHC size additionally diminishes reverse causality concerns. This is because there are usually substantial time lags between the occurrence and discovery/accounting of large operational losses, which account for the majority of operational risk (Abdymomunov et al. (2020)). Crucially, it is at the discovery and accounting (not occurrence) of operational losses that a given banking organization or outside investors would realize impending operational losses and potentially act on such information.

Nonetheless, for robustness, we estimate regressions using lagged (as opposed to contem-

poraneous) total assets that precede the occurrence of operational losses. Table 11 presents the results. In Column (1), BHC assets are lagged while the control variables are contemporaneous. In Column (2), both BHC assets and control variables are lagged. Ln(Lagged Assets) has a positive sign and is statistically significant in both specifications.

[Insert Table 11 about here]

\subsection{Value-at-Risk Estimates}

Economic capital models have grown in popularity over the last couple of decades, particularly at large financial institutions (De Fontnouvelle et al. (2006)). They are customarily used to estimate the amount of risk capital that a firm needs to secure survival in a scenario that occurs in a probabilistic sense, often referred to as "Value at Risk" (VaR). In operational risk, Loss Distribution Approach (LDA) models are a common technique to estimate 
VaR. ${ }^{11}$ In this section, we use a simple LDA model to estimate the value that can be lost to operational loss events that occur in a given quarter.

For every institution in our sample, we first estimate a frequency distribution $\rho\left(N_{t}\right)$ that describes the number of loss events $N_{t}$ in a given quarter $t$. We follow industry practice and assume that the frequency distribution follows a Poisson distribution with a parameter $\lambda$ equal to the average number of events per quarter. Then, we estimate a severity distribution $f\left(X_{i, t}\right)$ that describes the loss amount of a single loss event $X_{i, t}$ that occurs in period $t$. To estimate the severity distribution, there are two main alternatives: use the empirical distribution of dollar losses, or alternatively, fit the dollar losses into a parametric distribution and use the estimated parameters to generate individual losses. In our analysis, we follow the former approach, where we further adjust the dollar losses for inflation, using 2016:Q4 as a reference point. Finally, the convolution of the frequency and severity distributions gives rise to the quarterly loss distribution. The steps of the convolution are as follows: 1) draw a number of quarterly events $\left(N_{t}\right)$ from the frequency distribution; 2) draw $N_{t}$ losses from the severity distribution $f\left(X_{i, t}\right)$ (for simplicity, we assume that the frequency and severity distributions are independent); 3) sum the $N_{t}$ losses drawn from step 2 and obtain one quarterly loss $\left.L_{t}=\sum_{i=1}^{N_{t}} X_{i, t} ; 4\right)$ repeat steps 1 through 3100,000 times to obtain a series of quarterly simulated losses; 5) rank all the simulated quarterly losses $L_{t}$ and determine the quarterly loss corresponding to a given quantile.

Using the above modeling approach, we produce estimates of the value that can be lost by the 38 BHCs in our sample at the $10^{\text {th }}, 25^{\text {th }}, 50^{\text {th }}, 75^{\text {th }}, 90^{\text {th }}, 99^{\text {th }}$ percentiles of their loss distributions. We then fit linear and quadratic lines through the estimated losses as functions of asset size. Table 12 presents the linear and quadratic estimates, while Figure 4

\footnotetext{
${ }^{11}$ The LDA is the most common methodology used by large financial institutions around the world to quantify required capital for operational risk under the Advanced Measurement Approaches (AMA), one of the three methods allowed by Basel II regulation (Basel Committee on Banking Supervision (2006)). For a detailed discussion of LDA modeling, see Klugman et al. (1998) and Embrechts et al. (2004).
} 
presents the same visually.

[Insert Table 12 and Figure 4 about here]

Our Value-at-Risk estimates offer at least two important insights. First, the estimates indicate that operational losses are an important and potentially very costly source of risk for BHCs, which could result in multi-billion dollar losses to operational risk events that occur in a single calendar quarter for the more severe and less probable potential loss outcomes. Second, there are potentially important non-linearities between banking organization size and operational losses, which are especially pronounced for the more severe and less probable high quantiles of the bank loss distributions. It is important to emphasize that the linear and quadratic fits are based on information from all BHCs in the sample and thus cannot be used to identify loss quantiles for specific institutions.

\section{Conclusion}

This study makes an important contribution to the ongoing debate on the effects and implications of very large banking organizations. We focus on the largest U.S. BHCs for which a regulatory framework, the Dodd-Frank Wall Street Reform and Consumer Protection Act, provides us with rich and detailed data to carry out our empirical tests. Using a sample of 299,673 individual loss events from the 38 largest BHCs over the period 2001-2016, we present new evidence that links banking organization size to operational risk.

We show that larger BHCs have more operational risk and experience higher operational losses per dollar of assets. This relation is driven by losses from failures in obligations to clients, faulty product design and business practices, and to a lesser extent by losses from the disruption of business or system failures. Past operational problems are particularly 
persistent at the largest institutions, suggesting that size hinders efficient reformation and elimination of operationally risk practices. The relation between operational risk and BHC size is also amplified by the business cycle - the largest institutions are particularly susceptible to the incidence of higher operational losses during economic downturns. Finally, we also document that the increased exposure to operational risk at the largest banking organizations manifests through a higher frequency of particularly severe and potentially destabilizing tail risk events.

We conclude that banking organization size is an important factor for exposures to operational risk in the cross-section of large institutions. Our study highlights a particular channel through which size destroys value, counteracting efficiencies arising from scale economies. It thus helps reconcile existing literature that larger BHCs do not have higher valuations, despite "operational leverage." From a practitioner's perspective, our findings have implications for corporate risk management as well as policy and supervision. Our results suggest that the largest BHCs could benefit from tightening risk management practices and standards with regards to operational risk. Our findings also implicitly support supervision approaches that subject the largest financial institutions to heightened risk management and governance standards, and have higher expectations with regards to capital planning and adequacy. 


\section{References}

Abdymomunov, A., Curti, F., and Mihov, A. (2020). U.S. banking sector operational losses and the macroeconomic environment. Journal of Money, Credit and Banking, 52(1):115144. https://doi.org/10.1111/jmcb.12661.

Abdymomunov, A. and Mihov, A. (2019). Operational risk and risk management quality: Evidence from U.S. bank holding companies. Journal of Financial Services Research, 56 (1):73-93. https://doi.org/10.1007/s10693-017-0284-3.

Adams, R. and Driscoll, J. (2018). How the largest bank holding companies grew: Organic growth or acquisitions? FEDS Notes. Washington: Board of Governors of the Federal Reserve System, December 21, 2018. https://doi.org/10.17016/2380-7172.2282.

Afonso, G., Curti, F., and Mihov, A. (2019). Coming to terms with operational risk. Federal Reserve Bank of New York Liberty Street Economics.

Afonso, G., Santos, J. A. C., and Traina, J. (2014). Do "too-big-to-fail" banks take on more risk? Economic Policy Review, 20(2):41 - 58.

Ahmed, A. S., Takeda, C., and Thomas, S. (1999). Bank loan loss provisions: A reexamination of capital management, earnings management and signaling effects. Journal of Accounting and Economics, 28(1):1 - 25. https://doi.org/10.1016/s0165-4101(99)00017-8.

Allen, L. and Bali, T. G. (2007). Cyclicality in catastrophic and operational risk measurements. Journal of Banking \& Finance, 31(4):1191 - 1235. https://doi.org/10.1016/j.jbankfin.2006.10.007.

Basel Committee on Banking Supervision. International convergence of capital measurement and capital standards. Bank of International Settlements, 2006.

Chernobai, A., Jorion, P., and Yu, F. (2011). The determinants of operational risk in U.S. financial institutions. Journal of Financial and Quantitative Analysis, 46:1683-1725. https://doi.org/10.1017/s0022109011000500.

Chernobai, A., Ozdagli, A., and Wang, J. (2018). Business complexity and risk management: Evidence from operational risk events in U.S. bank holding companies. Journal of Monetary Economics, Forthcoming.

Chernobai, A. and Rachev, S. (2006). Applying robust methods to operational risk modeling. Journal of Operational Risk, 1(1):27-41. https://doi.org/10.21314/jop.2006.003.

Cope, E. W. and Carrivick, L. (2013). Effects of the financial crisis on banking operational losses. Journal of Operational Risk, 8(3):3 - 29. https://doi.org/10.21314/jop.2013.125. 
Cope, E. W., Piche, M. T., and Walter, J. S. (2012). Macroenvironmental determinants of operational loss severity. Journal of Banking $\mathcal{E}$ Finance, 36(5):1362 - 1380. https://doi.org/10.1016/j.jbankfin.2011.11.022.

Cummins, J. D., Lewis, C. M., and Wei, R. (2006). The market value impact of operational loss events for US banks and insurers. Journal of Banking \& Finance, 30(10):2605 - 2634. https://doi.org/10.1016/j.jbankfin.2005.09.015.

Curti, F. and Migueis, M. (2019). The information value of past losses in operational risk. Working Paper, Federal Reserve System.

de Fontnouvelle, P., Dejesus-Rueff, V., Jordan, J. S., and Rosengren, E. S. (2006). Capital and risk: New evidence on implications of large operational losses. Journal of Money, Credit and Banking, 38(7):1819-1846.

Demirgüç-Kunt, A. and Huizinga, H. (2013). Are banks too big to fail or too big to save? International evidence from equity prices and CDS spreads. Journal of Banking $\mathscr{E}$ Finance, 37(3):875 - 894. https://doi.org/10.1016/j.jbankfin.2012.10.010.

Ellul, A. and Yerramilli, V. (2013). Stronger risk controls, lower risk: Evidence from U.S. bank holding companies. The Journal of Finance, 68(5):1757-1803. https://doi.org/10.1111/jofi.12057.

Embrechts, P., Kaufmann, R., and Samorodnitsky, G. (2004). Ruin theory revisited: stochastic models for operational risk. Risk Management for Central Bank Foreign Reserves, European Central Bank, pages 243-261.

Federal Reserve System. Regulatory capital rules: Implementation of risk-based capital surcharges for global systemically important bank holding companies. 2015.

Feng, G. and Serletis, A. (2010). Efficiency, technical change, and returns to scale in large U.S. banks: Panel data evidence from an output distance function satisfying theoretical regularity. Journal of Banking \& Finance, 34(1):127 - 138. https://doi.org/10.1016/j.jbankfin.2009.07.009.

Frame, W. S. and White, L. J. (2014). Technological change, financial innovation and diffusion in banking. Oxford Handbook of Banking, 2nd Edition edited by Allen Berger, Philip Molyneux, and John Wilson. https://doi.org/10.1093/oxfordhb/9780199688500.013.0011.

Gillet, R., Hubner, G., and Plunus, S. (2010). Operational risk and reputation in the financial industry. Journal of Banking \&3 Finance, 34(1):224 - 235. https://doi.org/10.1016/j.jbankfin.2009.07.020.

Gropp, R., Hakenes, H., and Schnabel, I. (2011). Competition, risk-shifting, and public bail-out policies. The Review of Financial Studies, 24(6):2084-2120. https://doi.org/10.1093/rfs/hhq114. 
Hess, C. (2011). The impact of the financial crisis on operational risk in the financial services industry: Empirical evidence. The Journal of Operational Risk, 6(1):23-35. https://doi.org/10.21314/jop.2011.087.

Hirtle, B., Kovner, A., and Plosser, M. (2018). The impact of supervision on bank performance. Journal of Finance, Forthcoming.

Hughes, J. P. and Mester, L. J. (2013). Who said large banks dont experience scale economies? Evidence from a risk-return-driven cost function. Journal of Financial Intermediation, 22(4):559 - 585. https://doi.org/10.1016/j.jfi.2013.06.004.

James, C. (1991). The losses realized in bank failures. The Journal of Finance, 46(4): 1223-1242. https://doi.org/10.1111/j.1540-6261.1991.tb04616.x.

Jarrow, R. A. (2008). Operational risk. Journal of Banking ES Finance, 32(5):870 - 879. https://doi.org/10.1016/j.jbankfin.2007.06.006.

Jobst, A. (2008). Operational risk: The sting is still in the tail but the poison depends on the dose. IMF Working Paper, 239(07).

Klugman, S. A., Panjer, H. H., and Willmot, G. E. Loss Models: From Data to Decision. Wiley, 1998.

Kovner, A., Vickery, J., and Zhou, L. (2014). Do big banks have lower operating costs? Economic Policy Review, 20(2):1 - 27.

Laeven, L. and Levine, R. (2007). Is there a diversification discount in financial conglomerates? Journal of Financial Economics, 85(2):331 - 367. https://doi.org/10.1016/j.jfineco.2005.06.001.

Minton, B. A., Stulz, R. M., and Taboada, A. G. (2019). Are the largest banks valued more highly? Review of Financial Studies, 32(12):4604-4652. https://doi.org/10.1093/rfs/hhz036.

Sarin, N. and Summers, L. (2016). Understanding bank risk through market measures. Brookings Papers on Economic Activity, 2016(2):57-127.

Wang, T. and Hsu, C. (2013). Board composition and operational risk events of financial institutions. Journal of Banking \&3 Finance, 37(6):2042 - 2051. https://doi.org/10.1016/j.jbankfin.2013.01.027.

Wheelock, D. C. and Wilson, P. W. (2012). Do large banks have lower costs? New estimates of returns to scale for U.S. banks. Journal of Money, Credit and Banking, 44(1):171-199. https://doi.org/10.1111/j.1538-4616.2011.00472.x. 


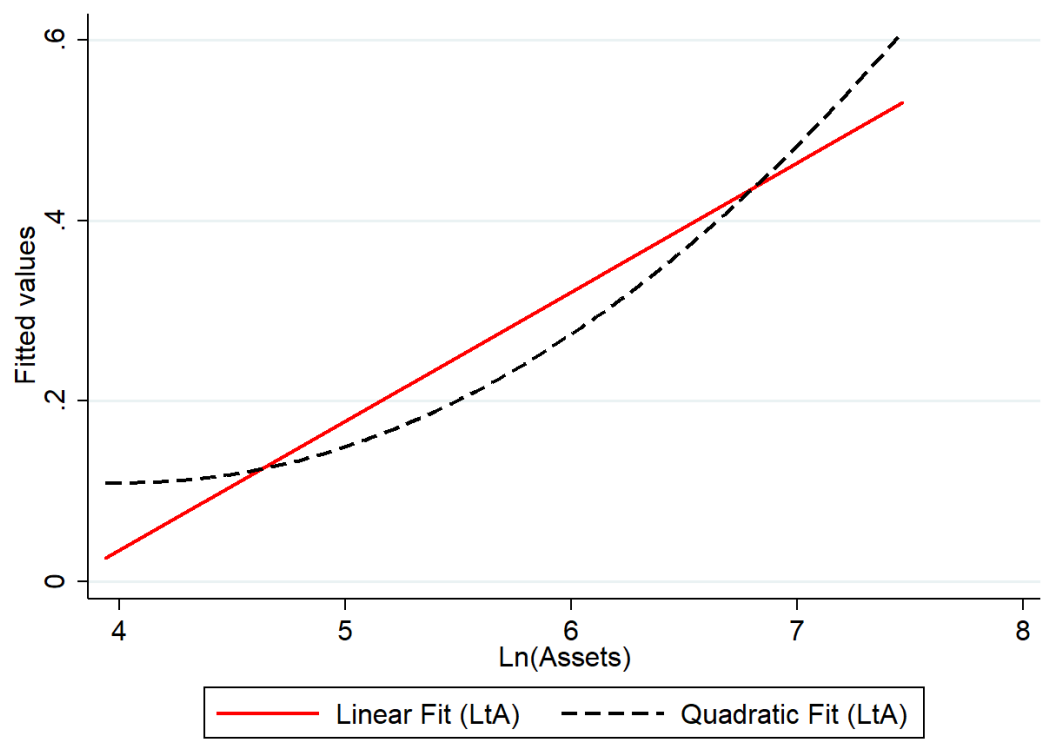

\section{Figure 1: Linear and Quadratic Fits}

The sample comprises an unbalanced panel of 1,343 quarterly losses incurred by 38 large U.S. bank holding companies over the period [2001:Q1-2016:Q4]. This figure presents linear and quadratic fits of relation between the average ratio of operational losses to total assets by BHC (multiplied by 1,000), LtA, and the average log-transformed total assets by BHC, Ln(Assets). 


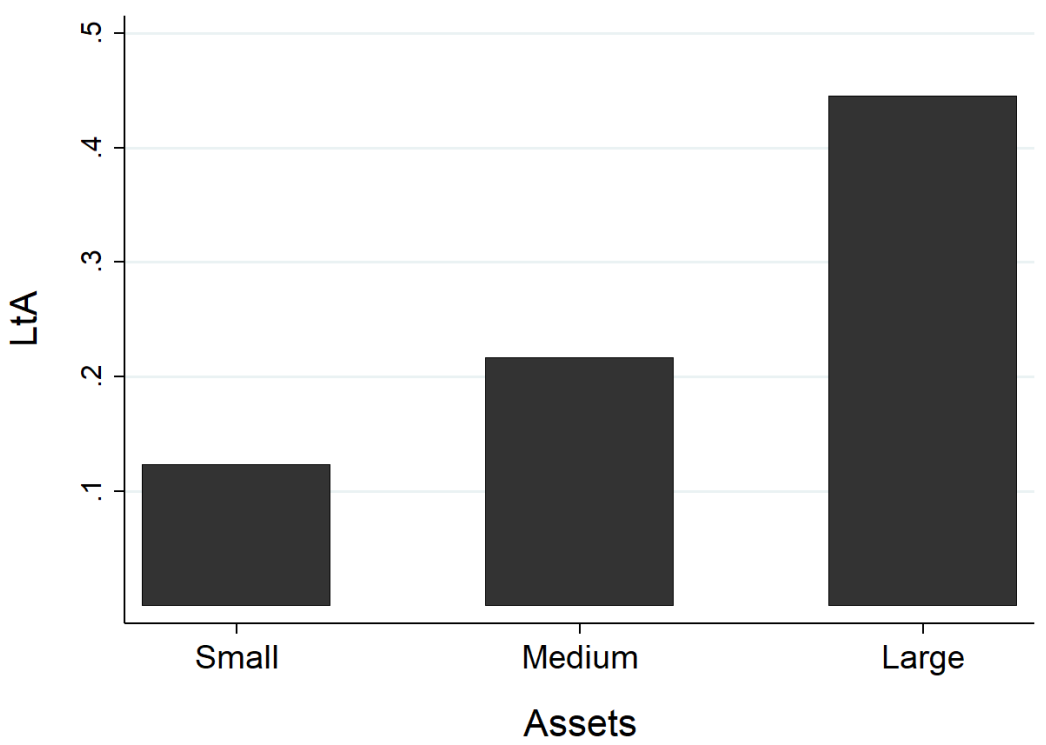

Figure 2: Operational Losses per Dollar of Assets by Size Groups

The sample comprises an unbalanced panel of 1,343 quarterly losses incurred by 38 large U.S. bank holding companies over the period [2001:Q1-2016:Q4]. This figure presents a bar chart of the average ratio of operational losses to total assets (multiplied by 1,000), LtA, for BHCs sorted in terciles based on total assets: "Small", "Medium", and "Large". The chart presents the average LtA across the three groups of holding companies. 


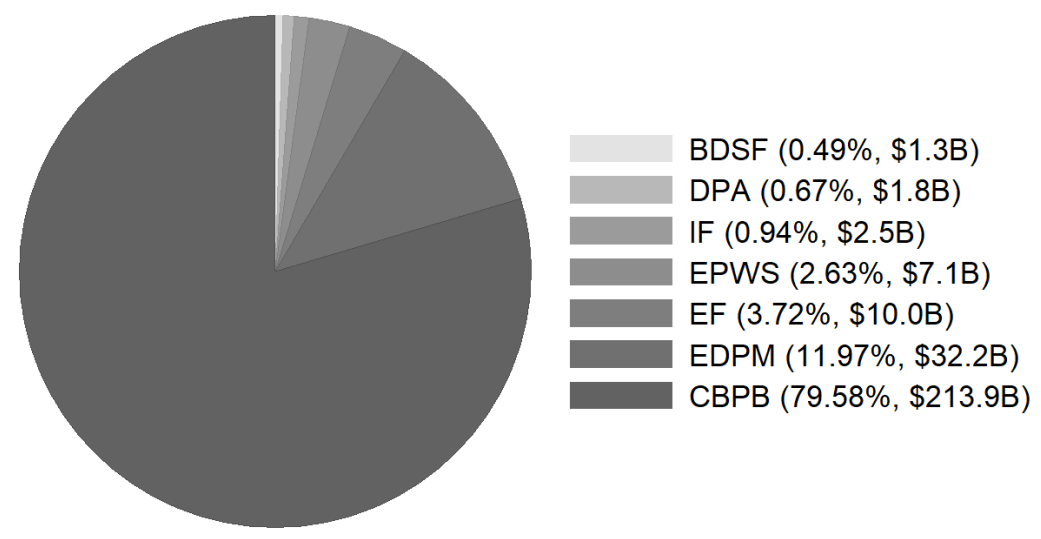

Figure 3: Operational Losses by Event Type

The sample includes 299,673 operational losses incurred by 38 large U.S. bank holding companies over the period [2001:Q1-2016:Q4]. This figure presents the allocation of losses, the percentage of total losses and U.S. Dollar loss amounts, among the 7 operational risk event type categories. The nomenclature for event types is as follows: Business Disruption and System Failures (BDSF), Damage to Physical Assets (DPA), Internal Fraud (IF), Employment Practices and Workplace Safety (EPWS), External Fraud (EF), Execution, Delivery and Process Management (EDPM), and Clients, Products and Business Practices (CPBP). 

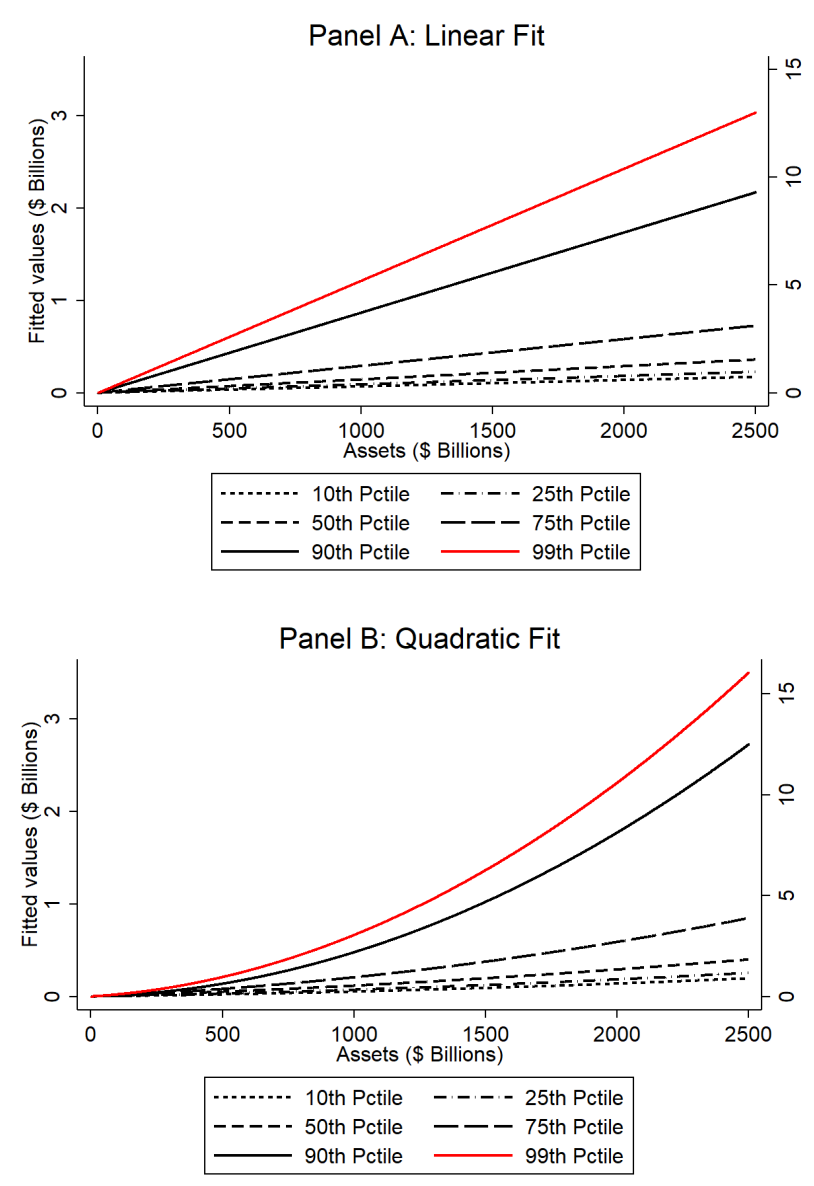

\section{Figure 4: Value-at-Risk Estimates}

This figure presents linear and quadratic fits of Value-at-Risk model estimates (in billions of 2016:Q4 constant dollars) at the $10^{\text {th }}, 25^{\text {th }}, 50^{\text {th }}, 75^{\text {th }}, 90^{\text {th }}, 99^{\text {th }}$ percentiles of the loss distributions of 38 large U.S. bank holding companies as a function of bank total assets. The $10^{\text {th }}, 25^{\text {th }}, 50^{\text {th }}, 75^{\text {th }}, 90^{\text {th }}$ percentile lines are plotted against the left vertical axis, while the $99^{\text {th }}$ percentile line is plotted against the right vertical axis. Panel A presents linear fits. Panel B presents quadratic fits. Note that the linear and quadratic fits are based on information from all BHCs in the sample and thus cannot be used to identify loss quantiles for individual BHCs. See Section 5.3 for more details on the Value-at-Risk model. 
Table 1: Operational Loss Event Type and Variable Definitions

This table presents variable definitions in Panel A and operational loss event type definitions according to Basel Committee on Banking Supervision (2006) in Panel B.

\begin{tabular}{|c|c|}
\hline \multicolumn{2}{|c|}{ Panel A: Variable Definitions } \\
\hline Variable & Definition \\
\hline Assets & BHC total assets in billions of U.S. Dollars \\
\hline Complexity (PC) & First principal component of $\operatorname{Ln}(N$ Subsidiaries $)$ and $\operatorname{Ln}(N$ Segments $)$ \\
\hline Freq & $\begin{array}{l}\text { The frequency of operational loss events that occur at a BHC over a } \\
\text { given calendar quarter. }\end{array}$ \\
\hline Fiduciary Activities & Income from fiduciary activities (as a proportion of total income) \\
\hline GSIB Score & $\begin{array}{l}\text { A measure of a BHC's systemic importance in billions as of 2016:Q4, } \\
\text { which aggregates } 12 \text { indicators across several conceptual categories: the } \\
\text { size of the financial institutions, their interconnectedness, the lack of } \\
\text { readily available substitutes for the services they provide, their com- } \\
\text { plexity, and their global (cross-jurisdictional) activities (Federal Reserve } \\
\text { System (2015)) }\end{array}$ \\
\hline Intra-FS Assets & $\begin{array}{l}\text { Intra-financial system assets as of 2016:Q4 (funds lent to financial institu- } \\
\text { tions (FIs), unused portion of committed lines extended to FIs, holdings } \\
\text { of securities issues by other FIs, net positive current exposure of securi- } \\
\text { ties financing transactions with FIs, OTC derivative contracts with FIs } \\
\text { that have a positive fair value) }\end{array}$ \\
\hline Intra-FS Liabilities & $\begin{array}{l}\text { Intra-financial system liabilities in billions as of 2016:Q4 (deposits due } \\
\text { to FIs, borrowings obtained from FIs, unused portion of committed lines } \\
\text { from FIs, net negative current exposure of securities financing transac- } \\
\text { tions with FIs, OTC derivative contracts with FIs that have a negative } \\
\text { fair value) }\end{array}$ \\
\hline Investment Banking & $\begin{array}{l}\text { Income from investment banking, advisory, brokerage and underwriting } \\
\text { fees (as a proportion of total income) }\end{array}$ \\
\hline Investment Securities & Interest income on investment securities (as a proportion of total income) \\
\hline Loan Losses & A BHC's loan charge-off rate \\
\hline Loans and Leases & Interest income on loans and leases (as a proportion of total income) \\
\hline Loss & $\begin{array}{l}\text { Operational losses that occur at a BHC over a given calendar quarter in } \\
\text { millions of U.S. Dollars }\end{array}$ \\
\hline $\operatorname{Ln}($ Freq $)$ & A natural log transformation of Freq \\
\hline $\operatorname{Ln}($ Loss $)$ & A natural log transformation of Loss \\
\hline Ln(Intra-FS Assets) & A natural log transformation of Intra-FS Assets \\
\hline Ln(Intra-FS Liabilities) & A natural log transformation of Intra-FS Liabilities \\
\hline Ln(N Employees) & A natural log transformation of $N$ Employees \\
\hline
\end{tabular}




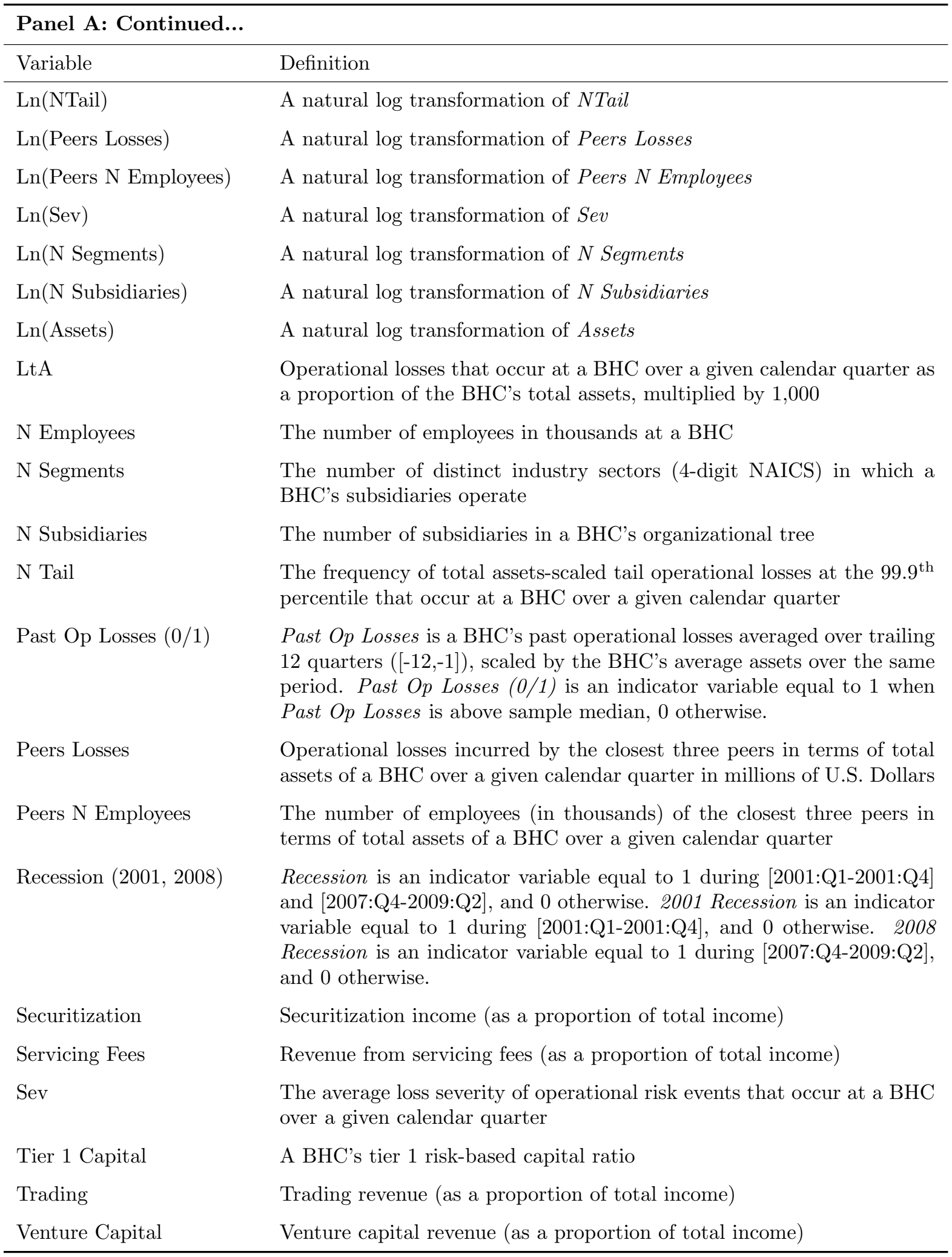




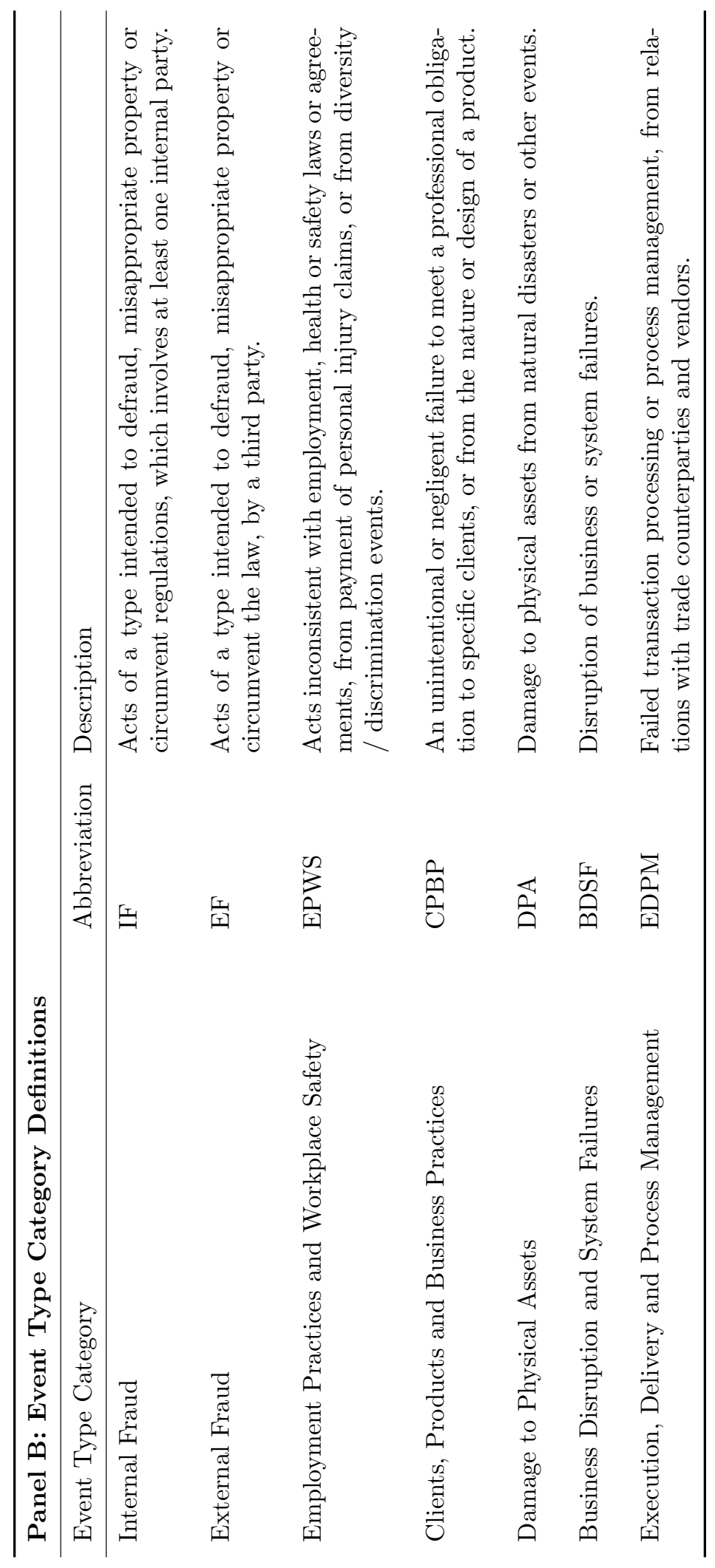


Table 2: Descriptive Statistics

This table presents descriptive statistics. The sample includes 1,343 quarterly observations of operational risk losses incurred by 38 large U.S. bank holding companies over the period [2001:Q1-2016:Q4] for which requisite data is available. The definitions of all variables are reported in Table 1.

\begin{tabular}{|c|c|c|c|c|c|c|}
\hline \multicolumn{7}{|c|}{ Panel A: Operational Risk Variables } \\
\hline & Mean & SD & $\mathrm{P} 25$ & $\mathrm{P} 50$ & P75 & $\mathrm{N}$ \\
\hline LtA & 0.265 & 1.011 & 0.030 & 0.071 & 0.178 & 1343 \\
\hline Loss & 200.156 & 1137.801 & 3.816 & 11.654 & 62.073 & 1343 \\
\hline Freq & 223.137 & 388.801 & 28.000 & 59.000 & 193.000 & 1343 \\
\hline Sev & 0.564 & 2.195 & 0.098 & 0.167 & 0.342 & 1343 \\
\hline $\mathrm{N}$ Tail & 0.174 & 0.482 & 0.000 & 0.000 & 0.000 & 1343 \\
\hline Peers Losses & 177.275 & 791.984 & 4.346 & 14.167 & 59.809 & 1343 \\
\hline
\end{tabular}

\begin{tabular}{|c|c|c|c|c|c|c|}
\hline \multicolumn{7}{|c|}{ Panel B: Other Variables } \\
\hline & Mean & SD & $\mathrm{P} 25$ & $\mathrm{P} 50$ & P75 & $\mathrm{N}$ \\
\hline Assets & 406.507 & 591.085 & 82.271 & 142.925 & 353.855 & 1343 \\
\hline Ln(Assets) & 5.268 & 1.124 & 4.410 & 4.962 & 5.869 & 1343 \\
\hline Loans and Leases & 0.472 & 0.201 & 0.366 & 0.517 & 0.612 & 1343 \\
\hline Investment Securities & 0.133 & 0.106 & 0.076 & 0.105 & 0.161 & 1343 \\
\hline Fiduciary Activities & 0.077 & 0.145 & 0.007 & 0.026 & 0.055 & 1343 \\
\hline Trading & 0.031 & 0.070 & 0.004 & 0.012 & 0.041 & 1343 \\
\hline Investment Banking & 0.067 & 0.094 & 0.014 & 0.033 & 0.087 & 1343 \\
\hline Venture Capital & 0.002 & 0.007 & 0.000 & 0.000 & 0.002 & 1343 \\
\hline Securitization & 0.005 & 0.016 & 0.000 & 0.000 & 0.001 & 1343 \\
\hline Servicing Fees & 0.014 & 0.026 & 0.000 & 0.004 & 0.021 & 1343 \\
\hline Past Op Losses & 0.311 & 0.524 & 0.068 & 0.159 & 0.360 & 1343 \\
\hline Loan Losses & 0.003 & 0.004 & 0.001 & 0.002 & 0.005 & 1343 \\
\hline Tier 1 Capital & 0.111 & 0.039 & 0.091 & 0.115 & 0.132 & 1343 \\
\hline N Subsidiaries & 414.702 & 780.913 & 36.000 & 78.000 & 376.000 & 1343 \\
\hline N Segments & 14.991 & 7.967 & 10.000 & 13.000 & 18.000 & 1343 \\
\hline Complexity (PC) & -0.024 & 1.368 & -0.813 & -0.094 & 0.807 & 1343 \\
\hline Intra-FS Assets & 58.783 & 94.832 & 2.685 & 13.753 & 49.618 & 1343 \\
\hline Intra-FS Liabilities & 62.181 & 103.980 & 3.664 & 12.950 & 83.794 & 1343 \\
\hline GSIB Score & 3.357 & 5.941 & 0.116 & 0.192 & 3.640 & 1343 \\
\hline Peers N Employees & 54.435 & 76.227 & 12.631 & 22.893 & 47.112 & 1343 \\
\hline
\end{tabular}




\section{Table 3: Correlations and Univariate Sorts}

The sample includes 1,343 quarterly observations of operational risk losses incurred by 38 large U.S. bank holding companies over the period [2001:Q1-2016:Q4] for which requisite data is available. Panel A presents variable correlations. Panel B displays averages of operational risk measures sorted in terciles based on BHC total assets. The definitions of all variables are reported in Table 1.

\begin{tabular}{lcccc}
\hline \multicolumn{5}{l}{ Panel A: Variable Correlations } \\
\hline Variables & LtA & $\operatorname{Ln}($ Loss $)$ & $\begin{array}{c}\text { Ln(N } \\
\text { Tail) }\end{array}$ & Ln(Assets) \\
\hline LtA & 1.000 & & & \\
& & & & \\
Ln(Loss) & 0.457 & 1.000 & & \\
& $(0.000)$ & & & \\
Ln(N Tail) & 0.534 & 0.583 & 1.000 & \\
& $(0.000)$ & $(0.000)$ & & \\
Ln(Assets) & 0.146 & 0.753 & 0.165 & 1.000 \\
& $(0.000)$ & $(0.000)$ & $(0.000)$ & \\
\hline
\end{tabular}

\begin{tabular}{lccccc}
\hline \multicolumn{2}{l}{ Panel B: Variable Sorts } \\
\hline & Small & Medium & Large & $(3)-(1)$ & p-Value \\
\hline LtA & 0.124 & 0.217 & 0.445 & 0.322 & 0.000 \\
Ln(L) & 1.604 & 2.567 & 4.492 & 2.888 & 0.000 \\
Ln(N Tail) & 0.066 & 0.102 & 0.160 & 0.094 & 0.000 \\
\hline
\end{tabular}




\section{Table 4: Operational Losses and BHC Size}

This table reports coefficients from panel regressions of operational loss measures on BHC size and control variables. The estimation sample comprises an unbalanced panel of 1,343 quarterly losses that occurred at 38 large U.S. bank holding companies over the period [2001:Q1-2016:Q4]. LtA measures the operational losses that occur at a BHC over a given calendar quarter as a proportion of the BHC's total assets, multiplied by 1,000. $L n($ Loss $)$ is a natural log transformation of operational dollar losses that occur at a BHC over a given calendar quarter. $L n($ Freq) is a natural $\log$ transformation of the frequency of operational losses that occur at a $\mathrm{BHC}$ over a given calendar quarter. $\mathrm{Ln}(\mathrm{Sev})$ is a natural log transformation of the average operational loss severity at a $\mathrm{BHC}$ over a given calendar quarter. Ln(Assets) is a natural log transformation of BHC total assets over a given calendar quarter. The definitions of all variables are reported in Table 1. All specifications include quarter fixed effects. The error terms are clustered at the quarter and BHC levels. p-values are presented in parentheses.

\begin{tabular}{lcccc}
\hline & $(1)$ & $(2)$ & $(3)$ & $(4)$ \\
& LtA & Ln(Loss) & Ln(Freq) & Ln(Sev) \\
\hline Ln(Assets) & $0.095^{* *}$ & $1.157^{* * *}$ & $1.061^{* * *}$ & $0.049^{* * *}$ \\
& $(0.025)$ & $(0.000)$ & $(0.000)$ & $(0.008)$ \\
Loans and Leases & $-0.275^{*}$ & $-1.743^{* * *}$ & -0.828 & $-0.273^{* *}$ \\
& $(0.062)$ & $(0.003)$ & $(0.365)$ & $(0.046)$ \\
Investment Securities & -0.068 & $-1.461^{* *}$ & $-2.795^{* * *}$ & $0.509^{* *}$ \\
& $(0.831)$ & $(0.043)$ & $(0.006)$ & $(0.027)$ \\
Fiduciary Activities & -0.115 & -0.704 & 0.073 & -0.230 \\
& $(0.465)$ & $(0.288)$ & $(0.932)$ & $(0.123)$ \\
Trading & -1.005 & -1.173 & -0.928 & -0.180 \\
& $(0.185)$ & $(0.272)$ & $(0.359)$ & $(0.564)$ \\
Investment Banking & -0.200 & -1.190 & $-1.856^{* *}$ & 0.246 \\
& $(0.446)$ & $(0.108)$ & $(0.048)$ & $(0.162)$ \\
Venture Capital & 2.833 & -1.321 & 7.472 & $-3.788^{*}$ \\
Securitization & $(0.663)$ & $(0.816)$ & $(0.109)$ & $(0.087)$ \\
& 1.717 & 2.330 & 0.868 & 1.120 \\
Servicing Fees & $(0.432)$ & $(0.381)$ & $(0.797)$ & $(0.397)$ \\
Past Op Losses & 0.524 & -0.306 & 3.758 & $-1.011^{* *}$ \\
& $(0.476)$ & $(0.876)$ & $(0.173)$ & $(0.014)$ \\
Loan Losses & $0.277^{* *}$ & $0.478^{* * *}$ & $0.366^{* * *}$ & 0.017 \\
& $(0.022)$ & $(0.001)$ & $(0.004)$ & $(0.534)$ \\
Tier 1 Capital & 3.423 & $37.452^{* *}$ & $32.052^{* *}$ & 1.007 \\
& $(0.688)$ & $(0.012)$ & $(0.033)$ & $(0.765)$ \\
& 0.104 & -0.966 & 0.268 & -0.867 \\
Observations & $(0.876)$ & $(0.521)$ & $(0.865)$ & $(0.228)$ \\
Adjusted $R^{2}$ & 1343 & 1343 & 1343 & 1343 \\
$*{ }^{*} p<0.10,{ }^{* *} p<0.05,{ }^{* * *}$ & 0.18 & 0.73 & 0.82 & 0.22 \\
& $0<0.01$ & & & \\
& & & &
\end{tabular}




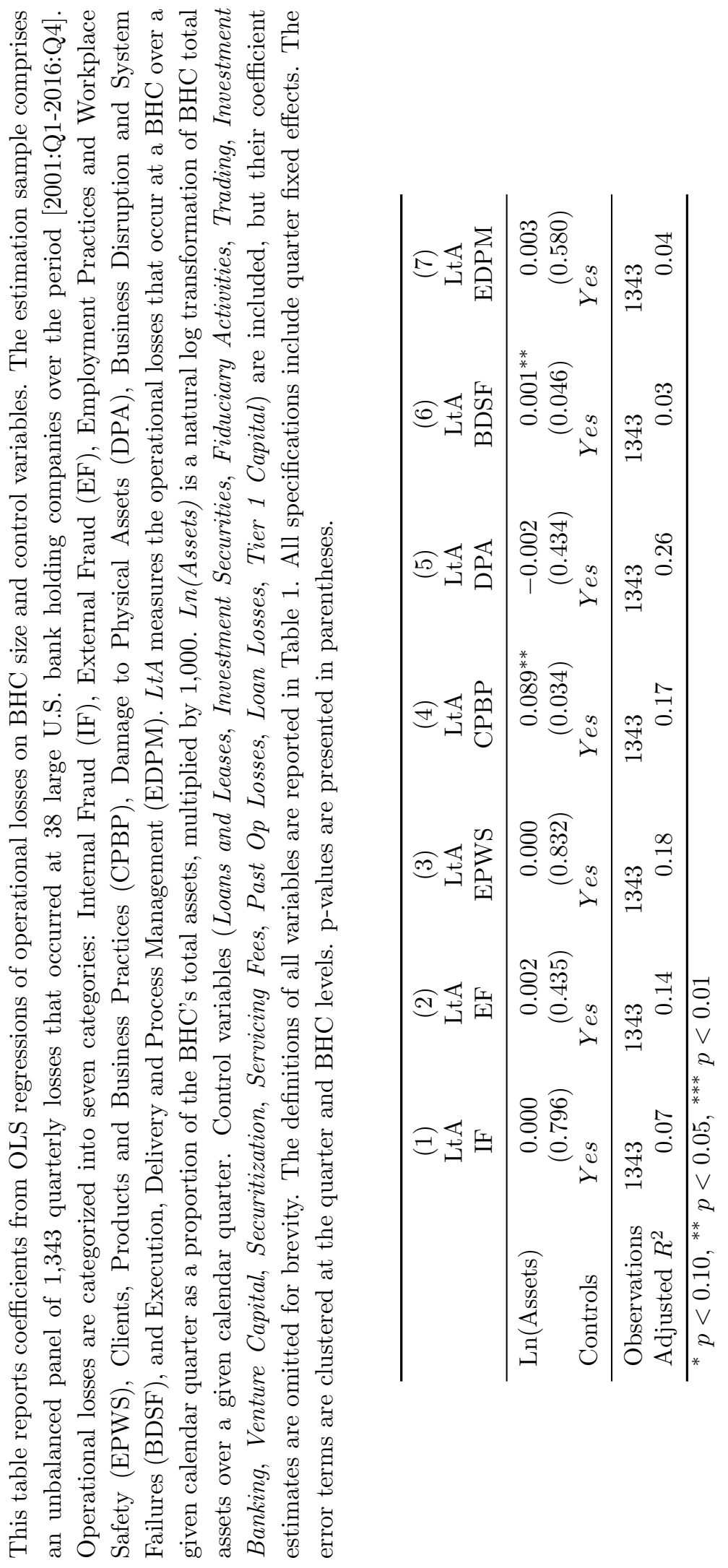


Table 6: Past Operational Losses

This table reports coefficients from panel regressions of operational losses on BHC size, measures of past losses, their interactions and control variables. The estimation sample comprises an unbalanced panel of 1,343 quarterly losses that occurred at 38 large U.S. bank holding companies over the period [2001:Q1-2016:Q4]. LtA measures the operational losses that occur at a BHC over a given calendar quarter as a proportion of the bank's total assets, multiplied by 1,000. Ln(Assets) is a natural log transformation of BHC total assets over a given calendar quarter. Past Op Losses are a BHC's past quarterly operational losses averaged over trailing 12 quarters $([-12,-1])$, scaled by the BHC's average assets over the same period. Past Op Losses (0/1) is an indicator variable equal to 1 when Past Op Losses is above sample median, 0 otherwise. Control variables (Loans and Leases, Investment Securities, Fiduciary Activities, Trading, Investment Banking, Venture Capital, Securitization, Servicing Fees, Loan Losses, Tier 1 Capital) are included, but their coefficient estimates are omitted for brevity. The definitions of all variables are reported in Table 1. All specifications include quarter fixed effects. The error terms are clustered at the quarter and BHC levels. p-values are presented in parentheses.

\begin{tabular}{lcc}
\hline & $(1)$ & $(2)$ \\
& LtA & LtA \\
\hline Ln(Assets) & 0.055 & 0.023 \\
& $(0.189)$ & $(0.427)$ \\
Past Op Losses*Ln(Assets) & $0.113^{* *}$ & \\
& $(0.014)$ & \\
Past Op Losses & -0.407 & \\
& $(0.102)$ & \\
Past Op Losses $(0 / 1)^{*} \operatorname{Ln}($ Assets) & & $0.151^{* *}$ \\
Past Op Losses $(0 / 1)$ & & $(0.029)$ \\
& & $-0.625^{* *}$ \\
Controls & $Y$ Yes & $(0.039)$ \\
\hline Observations & 1343 & 1343 \\
Adjusted $R^{2}$ & 0.18 & 0.17 \\
\hline${ }^{*} p<0.10,{ }^{* *} p<0.05,{ }^{* * *} p<0.01$ & &
\end{tabular}




\section{Table 7: Economic Downturns}

This table reports coefficients from panel regressions of operational losses on BHC size and control variables. The estimation sample comprises an unbalanced panel of 1,343 quarterly losses that occurred at 38 large U.S. bank holding companies over the period [2001:Q1-2016:Q4]. LtA measures the operational losses that occur at a BHC over a given calendar quarter as a proportion of the bank's total assets, multiplied by 1,000. Ln(Assets) is a natural log transformation of $\mathrm{BHC}$ total assets over a given calendar quarter. Recession is an indicator variable that equals 1 during the periods [2001:Q1-2001:Q4] and [2007:Q4-2009:Q2], and 0 otherwise. 2001 Recession is an indicator variable that equals 1 during the period [2001:Q1-2001:Q4], and 0 otherwise. 2008 Recession is an indicator variable that equals 1 during the period [2007:Q4-2009:Q2], and 0 otherwise. Control variables (Loans and Leases, Investment Securities, Fiduciary Activities, Trading, Investment Banking, Venture Capital, Securitization, Servicing Fees, Past Op Losses, Loan Losses, Tier 1 Capital) are included, but their coefficient estimates are omitted for brevity. The definitions of all variables are reported in Table 1. All specifications include quarter fixed effects. The error terms are clustered at the quarter and BHC levels. p-values are presented in parentheses.

\begin{tabular}{lccc}
\hline & $(1)$ & $(2)$ & $(3)$ \\
& LtA & LtA & LtA \\
\hline Ln(Assets) & 0.054 & $0.093^{*}$ & $0.073^{*}$ \\
& $(0.112)$ & $(0.065)$ & $(0.073)$ \\
Recession*Ln(Assets) & $0.338^{* *}$ & & \\
& $(0.010)$ & & \\
2001 Recession*Ln(Assets) & & $1.169^{*}$ & \\
& & $(0.059)$ & \\
2008 Recession*Ln(Assets) & & & $0.186^{* *}$ \\
& $Y$ es & Yes & $(0.042)$ \\
Controls & 1343 & 1343 & 1343 \\
\hline Observations & 0.20 & 0.21 & 0.18 \\
Adjusted $R^{2}$ & & &
\end{tabular}


Table 8: Tail Operational Risk

This table reports coefficients from regressions of tail operational risk on BHC size and control variables. The estimation sample comprises an unbalanced panel of 1,343 quarterly losses that occurred at 38 large U.S. bank holding companies over the period [2001:Q1-2016:Q4]. $N$ Tail is the frequency of total assetsscaled tail operational losses at the $99.9^{\text {th }}$ percentiles that occur at a BHC over a given calendar quarter. $\operatorname{Ln}(N$ Tail) is a natural $\log$ transformation of (1 plus) $N$ Tail. Ln(Assets) is a natural log transformation of BHC total assets over a given calendar quarter. Past Op Losses are a BHC's past quarterly operational losses averaged over trailing 12 quarters $([-12,-1])$, scaled by the BHC's average assets over the same period. Recession is an indicator variable that equals 1 during the periods [2001:Q1-2001:Q4] and [2007:Q4-2009:Q2], and 0 otherwise. Control variables (Loans and Leases, Investment Securities, Fiduciary Activities, Trading, Investment Banking, Venture Capital, Securitization, Servicing Fees, Past Op Losses, Loan Losses, Tier 1 Capital) are included, but their coefficient estimates are omitted for brevity. The definitions of all variables are reported in Table 1. Column (1), (4) and (5) present OLS regression estimates. Columns (2) and (3) present Poisson and Negative Binomial regression estimates, respectively. All specifications include quarter fixed effects. The error terms are clustered at the quarter and BHC levels. p-values are presented in parentheses.

\begin{tabular}{|c|c|c|c|c|c|}
\hline & $\begin{array}{c}(1) \\
\text { Ln(N Tail) } \\
\text { OLS }\end{array}$ & $\begin{array}{c}(2) \\
\text { N Tail } \\
\text { Poisson }\end{array}$ & $\begin{array}{c}(3) \\
\text { N Tail } \\
\text { NB }\end{array}$ & $\begin{array}{c}(4) \\
\operatorname{Ln}(\mathrm{N} \text { Tail }) \\
\text { OLS }\end{array}$ & $\begin{array}{c}(5) \\
\operatorname{Ln}(\mathrm{N} \text { Tail }) \\
\text { OLS }\end{array}$ \\
\hline Ln(Assets) & $\begin{array}{c}0.028^{* *} \\
(0.021)\end{array}$ & $\begin{array}{l}0.262^{* * *} \\
(0.002)\end{array}$ & $\begin{array}{l}0.253^{* * *} \\
(0.002)\end{array}$ & $\begin{array}{c}0.018 \\
(0.137)\end{array}$ & $\begin{array}{c}0.021^{*} \\
(0.075)\end{array}$ \\
\hline Past Op Losses*Ln(Assets) & & & & $\begin{array}{c}0.028^{* *} \\
(0.027)\end{array}$ & \\
\hline Recession*Ln(Assets) & & & & & $\begin{array}{c}0.060^{* *} \\
(0.034)\end{array}$ \\
\hline Controls & Yes & Yes & Yes & Yes & Yes \\
\hline Observations & 1343 & 1343 & 1343 & 1343 & 1343 \\
\hline Adjusted $R^{2}$ & 0.12 & & & 0.12 & 0.12 \\
\hline
\end{tabular}




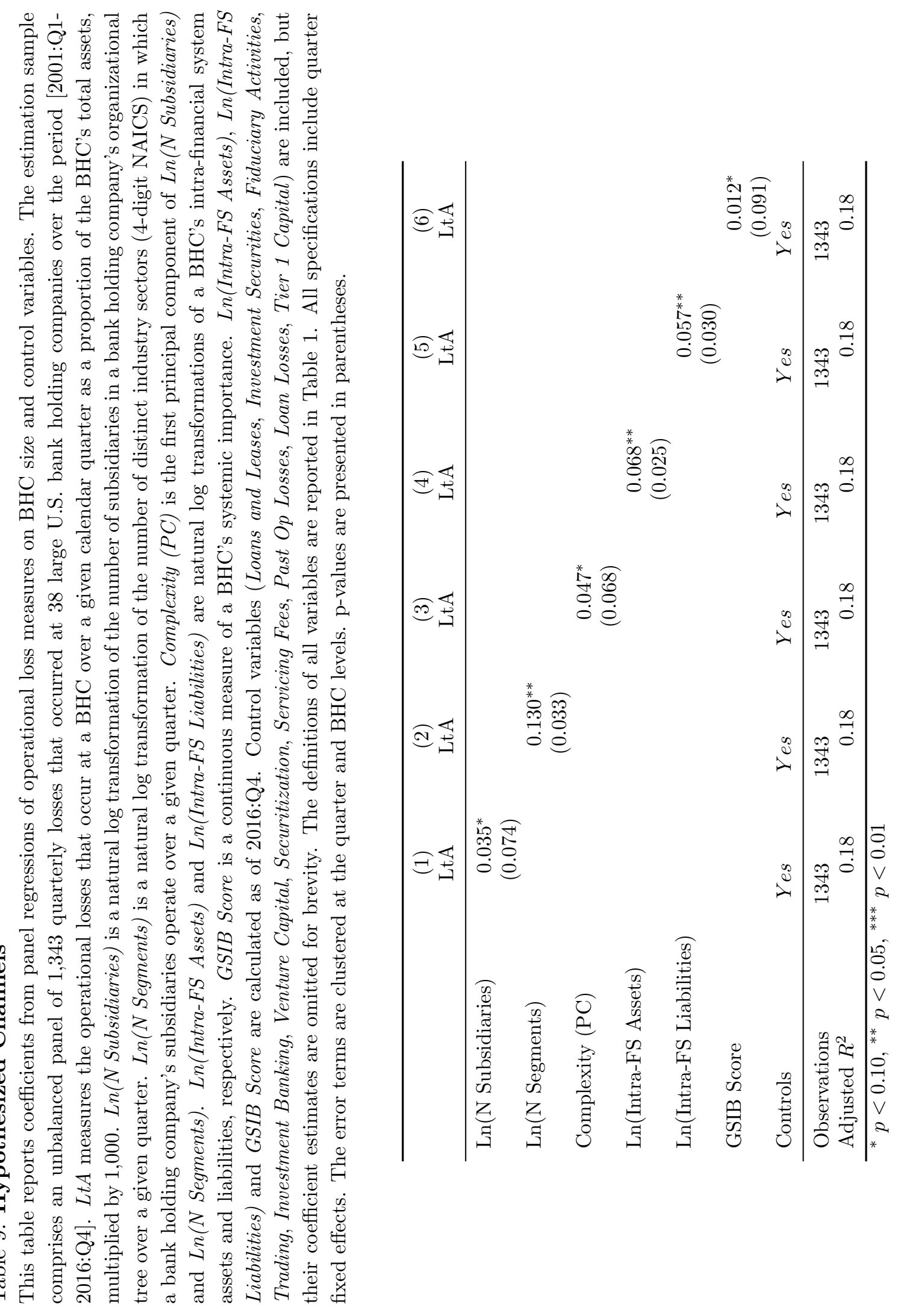




\section{Table 10: Instrumental Variables}

This table reports coefficients from instrumental variable regressions of operational losses on BHC size and control variables. The estimation sample comprises an unbalanced panel of 1,343 quarterly losses that occurred at 38 large U.S. bank holding companies over the period [2001:Q1-2016:Q4]. LtA measures the operational losses that occur at a BHC over a given calendar quarter as a proportion of the bank's total assets, multiplied by 1,000. Ln(Assets) is a natural log transformation of BHC total assets over a given calendar quarter. We use the following instrumental variables: the operational losses of the closest three BHCs in terms of total assets; the number of employees of the closest three BHCs in terms of total assets. The definitions of all variables are reported in Table 1. Panel A presents first stage results. Panel B presents second stage results. The error terms are clustered at the quarter and BHC levels. p-values are presented in parentheses.

\begin{tabular}{|c|c|c|}
\hline \multicolumn{3}{|c|}{ Panel A: First Stage Regressions } \\
\hline & $(1)$ & $(2)$ \\
\hline & Ln(Assets) & Ln(Assets) \\
\hline \multirow[t]{2}{*}{ Ln(Peers Losses) } & $0.372^{* * *}$ & \\
\hline & $(0.000)$ & \\
\hline \multirow[t]{2}{*}{ Ln(Peers N Employees) } & & $0.939^{* * *}$ \\
\hline & & $(0.000)$ \\
\hline \multirow[t]{2}{*}{ Loans and Leases } & $-0.907^{* *}$ & -0.320 \\
\hline & $(0.021)$ & $(0.144)$ \\
\hline \multirow[t]{2}{*}{ Investment Securities } & $2.287^{* * *}$ & 0.506 \\
\hline & $(0.009)$ & $(0.255)$ \\
\hline \multirow[t]{2}{*}{ Fiduciary Activities } & $-1.515^{* * *}$ & $-0.566^{*}$ \\
\hline & $(0.001)$ & $(0.062)$ \\
\hline \multirow[t]{2}{*}{ Trading } & 1.144 & 0.053 \\
\hline & $(0.143)$ & $(0.896)$ \\
\hline \multirow[t]{2}{*}{ Investment Banking } & 0.582 & $0.955^{*}$ \\
\hline & $(0.487)$ & $(0.094)$ \\
\hline \multirow[t]{2}{*}{ Venture Capital } & 6.246 & 4.930 \\
\hline & $(0.301)$ & $(0.235)$ \\
\hline \multirow[t]{2}{*}{ Securitization } & -1.883 & -1.278 \\
\hline & $(0.446)$ & $(0.437)$ \\
\hline \multirow[t]{2}{*}{ Servicing Fees } & 0.345 & -1.858 \\
\hline & $(0.919)$ & $(0.387)$ \\
\hline \multirow[t]{2}{*}{ Past Op Losses } & 0.120 & 0.013 \\
\hline & $(0.153)$ & $(0.823)$ \\
\hline \multirow[t]{2}{*}{ Loan Losses } & 14.988 & $12.319^{*}$ \\
\hline & $(0.124)$ & $(0.050)$ \\
\hline \multirow{2}{*}{ Tier 1 Capital } & $4.645^{* *}$ & 0.890 \\
\hline & $(0.022)$ & $(0.424)$ \\
\hline Observations & 1343 & 1343 \\
\hline Adjusted $R^{2}$ & 0.66 & 0.87 \\
\hline
\end{tabular}




\begin{tabular}{lcc}
\hline Panel B: Second Stage Regressions & \\
& $(1)$ & $(2)$ \\
& LtA & LtA \\
\hline Ln(Assets) & $0.178^{* * *}$ & $0.083^{* *}$ \\
& $(0.000)$ & $(0.016)$ \\
Loans and Leases & 0.139 & 0.068 \\
& $(0.619)$ & $(0.798)$ \\
Investment Securities & -0.181 & 0.235 \\
& $(0.678)$ & $(0.579)$ \\
Fiduciary Activities & 0.340 & 0.200 \\
& $(0.196)$ & $(0.388)$ \\
Trading & $-0.778^{*}$ & -0.550 \\
& $(0.093)$ & $(0.271)$ \\
Investment Banking & -0.329 & -0.172 \\
& $(0.402)$ & $(0.583)$ \\
Venture Capital & 2.049 & 3.486 \\
& $(0.813)$ & $(0.675)$ \\
Securitization & 2.478 & 2.790 \\
& $(0.203)$ & $(0.190)$ \\
Servicing Fees & 0.589 & 0.931 \\
& $(0.527)$ & $(0.248)$ \\
Past Op Losses & $0.279^{* * *}$ & $0.319^{* * *}$ \\
& $(0.007)$ & $(0.002)$ \\
Loan Losses & -2.349 & 1.556 \\
& $(0.777)$ & $(0.855)$ \\
Tier 1 Capital & $-1.601^{* * *}$ & $-1.186^{* *}$ \\
& $(0.006)$ & $(0.019)$ \\
\hline Observations & 1343 & 1343 \\
Adjusted $R^{2}$ & 0.05 & 0.05 \\
\hline${ }^{*} p<0.10,{ }^{* *} p<0.05,{ }^{* * *} p<0.01$ & \\
& &
\end{tabular}




\section{Table 11: Lagged BHC Size}

This table reports coefficients from panel regressions of operational losses on lagged BHC size and control variables. The estimation sample comprises an unbalanced panel of 1,305 quarterly losses that occurred at 38 large U.S. bank holding companies over the period [2001:Q2-2016:Q4]. LtA measures the operational losses that occur at a BHC over a given calendar quarter as a proportion of the BHC's total assets, multiplied by 1,000. Ln(Lagged Assets) is a natural log transformation of lagged BHC total assets. Control variables (Loans and Leases, Investment Securities, Fiduciary Activities, Trading, Investment Banking, Venture Capital, Securitization, Servicing Fees, Past Op Losses, Loan Losses, Tier 1 Capital) are included, but their coefficient estimates are omitted for brevity. Column (1) uses contemporaneous controls. Column (2) uses lagged controls. The definitions of all variables are reported in Table 1. All specifications include quarter fixed effects. The error terms are clustered at the quarter and BHC levels. p-values are presented in parentheses.

\begin{tabular}{lcc}
\hline & $(1)$ & $(2)$ \\
& LtA & LtA \\
\hline Ln(Lagged Assets) & $0.086^{* *}$ & $0.072^{* *}$ \\
& $(0.033)$ & $(0.026)$ \\
Controls & $Y e s$ & $Y e s$ \\
\hline Observations & 1305 & 1305 \\
Adjusted $R^{2}$ & 0.11 & 0.11 \\
\hline${ }^{*} p<0.10,^{* *} p<0.05,^{* * *} p<0.01$ &
\end{tabular}


Table 12: Value-at-Risk Estimates

This table presents linear and quadratic fits of Value-at-Risk model estimates (in billions of 2016:Q4 constant dollars) at the $10^{\text {th }}, 25^{\text {th }}, 50^{\text {th }}, 75^{\text {th }}, 90^{\text {th }}, 99^{\text {th }}$ percentiles of the loss distributions of 38 large U.S. bank holding companies as a function of bank total assets. Panel A presents linear fits. Panel B presents quadratic fits. Note that the linear and quadratic fits are based on information from all BHCs in the sample and thus cannot be used to identify loss quantiles for individual BHCs. See Section 5.3 for more details on the Value-at-Risk model.

\begin{tabular}{lcccccc}
\hline \multicolumn{2}{l}{ Panel A: Linear Fit } & & & & \\
\hline \multirow{2}{*}{ Assets } & Pctile & Pctile & Pctile & Pctile & Pctile & Pctile \\
\hline 50 & 0.003 & 0.005 & 0.007 & 0.015 & 0.043 & 0.260 \\
100 & 0.007 & 0.009 & 0.014 & 0.029 & 0.087 & 0.520 \\
250 & 0.017 & 0.023 & 0.036 & 0.073 & 0.217 & 1.300 \\
500 & 0.034 & 0.045 & 0.072 & 0.145 & 0.434 & 2.600 \\
1000 & 0.069 & 0.091 & 0.144 & 0.290 & 0.868 & 5.200 \\
1500 & 0.103 & 0.136 & 0.216 & 0.435 & 1.302 & 7.800 \\
2000 & 0.138 & 0.182 & 0.288 & 0.580 & 1.736 & 10.400 \\
2500 & 0.172 & 0.227 & 0.360 & 0.725 & 2.170 & 13.000 \\
\hline
\end{tabular}

\begin{tabular}{lcccccc}
\hline \multicolumn{7}{l}{ Panel B: Quadratic Fit } \\
\hline \multirow{2}{*}{ Assets } & Pctile & Pctile & Pctile & Pctile & Pctile & Pctile \\
\hline 50 & 0.002 & 0.003 & 0.004 & 0.006 & 0.005 & 0.046 \\
100 & 0.004 & 0.005 & 0.009 & 0.013 & 0.011 & 0.104 \\
250 & 0.010 & 0.014 & 0.024 & 0.035 & 0.044 & 0.344 \\
500 & 0.022 & 0.031 & 0.051 & 0.081 & 0.138 & 0.967 \\
1000 & 0.053 & 0.072 & 0.116 & 0.206 & 0.479 & 3.057 \\
1500 & 0.092 & 0.123 & 0.196 & 0.375 & 1.024 & 6.268 \\
2000 & 0.139 & 0.184 & 0.290 & 0.588 & 1.773 & 10.601 \\
2500 & 0.195 & 0.254 & 0.399 & 0.845 & 2.724 & 16.056 \\
\hline \multicolumn{7}{l}{}
\end{tabular}

